\title{
Greenhouse gas emissions and energy balance of biodiesel production from microalgae cultivated in photobioreactors in Denmark: a life-cycle modeling
}

\author{
Monari, Chiara; Righi, Serena; Olsen, Stig Irving
}

Published in:

Journal of Cleaner Production

Link to article, DOI:

10.1016/j.jclepro.2015.08.112

Publication date:

2016

Document Version

Peer reviewed version

Link back to DTU Orbit

Citation (APA):

Monari, C., Righi, S., \& Olsen, S. I. (2016). Greenhouse gas emissions and energy balance of biodiesel production from microalgae cultivated in photobioreactors in Denmark: a life-cycle modeling. Journal of Cleaner Production, 112, 4084-4092. https://doi.org/10.1016/j.jclepro.2015.08.112

\section{General rights}

Copyright and moral rights for the publications made accessible in the public portal are retained by the authors and/or other copyright owners and it is a condition of accessing publications that users recognise and abide by the legal requirements associated with these rights.

- Users may download and print one copy of any publication from the public portal for the purpose of private study or research.

- You may not further distribute the material or use it for any profit-making activity or commercial gain

- You may freely distribute the URL identifying the publication in the public portal 


\section{6 words}

2

Greenhouse gas emissions and energy balance of biodiesel production from

microalgae cultivated in photobioreactors in Denmark: a life-cycle modeling

5

6

$$
\begin{aligned}
& \text { Chiara Monari }{ }^{1} \text {, Serena Righi }{ }^{1,2^{*}} \text {, Stig Irving Olsen }{ }^{3} \\
& { }^{1} \text { Centro Interdipartimentale di Ricerca per le Scienze Ambientali (CIRSA), }
\end{aligned}
$$
Alma Mater Studiorum - University of Bologna, via S. Alberto 163, 48123 Ravenna, Italy

${ }^{2}$ CIRI Energia e Ambiente, U.O. Biomasse, Alma Mater Studiorum - University of Bologna, via S. Alberto 163, 48123 Ravenna, Italy

${ }^{3}$ Department of Management Engineering (DTU-MAN), Quantitative Sustainability Section (QSA) Technical University of Denmark, 2800 Lyngby, Denmark

"Corresponding author

Tel.: +39-0544-937306; fax : +39-0544-937411

E-mail address: serena.righi2@unibo.it 


\section{$21 \quad$ Abstract}

22 The current use of fossil fuels is problematic for both environmental and economic reasons and biofuels are regarded as a potential solution to current energy issues. This study analyzes the energy balances and greenhouse gas emissions of 24 different technology scenarios for the production of algal biodiesel from Nannochloropsis cultivated at industrial scale in photobioreactors in Denmark. Both consolidated and pioneering technologies are analyzed focusing on strengths and weaknesses which influence the performance. Based on literature data, energy balance and greenhouse gas emissions are determined in a comparative 'well-to-tank' Life Cycle Assessment against fossil diesel. Use of by-products from biodiesel production such as glycerol obtained from transesterification and anaerobic digestion of residual biomass are included. Different technologies and methods are considered in cultivation stage (freshwater vs. wastewater; synthetic $\mathrm{CO}_{2}$ vs. waste $\mathrm{CO}_{2}$ ), harvesting stage (flocculation vs. centrifugation) and oil extraction stage (hexane extraction vs. supercritical $\mathrm{CO}_{2}$ extraction). The choices affecting environmental performance of the scenarios are evaluated. Results show that algal biodiesel produced through current conventional technologies has higher energy demand and greenhouse gas emissions than fossil diesel. However, greenhouse gas emissions of algal biodiesel can be significantly reduced through the use of 'waste' flows (nutrients and $\mathrm{CO}_{2}$ ) but there are still technical difficulties with both microalgae cultivation in wastewater as well as transportation and injection of waste $\mathrm{CO}_{2}$. In any way, a positive energy balance is still far from being achieved. Considerable improvements must be made to develop an environmentally beneficial microalgae biodiesel production on an industrial scale. In particular, different aspects of cultivation need to be enhanced, such as the use of wastewater and $\mathrm{CO}_{2}$-rich flue gas from industrial power plants. 
47 HIGHLIGHTS

48 - The best existing technologies for algal biodiesel production via PBRs have

$49 \quad$ been compared.

50 - Fossil diesel has been taken as reference product.

51 Energy balance and greenhouse gas emissions have been evaluated.

52 - Algal biodiesel has higher impacts compared to fossil diesel.

53 - Great improvements must be achieved to develop algal biodiesel on industrial

$54 \quad$ scale

\section{KEYWORDS}

56 Biofuel; Renewable fuels; Biorefinery; Bioenergy; Biogas; Nannochloropsis 


\section{Introduction}

59 The use of fossil fuels is increasingly problematic from both an economic and an

60 environmental point of view. It has been necessary to identify compatible mitigation

61 strategies to avoid the exhaustion of fossil fuels and minimize the excess of $\mathrm{CO}_{2}$ 62 emissions related to energy production (Ribeiro et al., 2007). In recent times, the

63 European Commission has presented the EU Directive 2009/28/CE aiming to establish

64 a target of $20 \%$ share of renewable energy sources in energy consumption by 2020 . In this context at least $10 \%$ of the energy for transportation must be based on renewable energy sources (European Commission, 2009). As a renewable energy source, biofuels are an attractive alternative to current petroleum based fuels (Festel et al., 2014). Biofuels refer to liquid, gas and solid fuels derived from biomass, including a.o. dedicated energy crops, residues from agriculture, and algae. Biofuels are classified as first (from crop based feedstock), second (from non-food feedstock), third (from algae) and fourth (from genetically engineered crops) generation fuels on the basis of the biomass origin and production technology (Demirbas, 2011; Lü et al., 2011; Liew et al., 2014).

Due to several features, algae are regarded as a promising source of biofuels and are considered an interesting alternative to current biofuel crops (Singh et al., 2011; Aitken et al., 2014). The production of fuel from algae provides many advantages: algae do not compete with land use and crop production since they are aquatic organisms; their growth rate is higher than that of terrestrial plants from which the first-generation biofuels derive (Scott et al., 2010); they do not need chemicals, herbicides, pesticides for growth (Kumar et al., 2010; Yang and Chen, 2012); they can remove nitrogen and phosphorus from wastewater (Clarens et al., 2010); and, under certain conditions, such as nitrogen stress, algae are characterized by high lipid accumulation, a feature that increases biofuel production (Rodolfi et al., 2009). 
84 On the other hand, there are several difficulties associated with the production of the

85 third-generation biofuels and, until now, their commercial production has not been achieved on industrial scale in a cost-efficient manner (Biofuel.org.uk, 2010). Currently, only a few pilot plant projects have been developed (e.g. BFS Bio Fuel Systems, 2015; All-gas, 2012). At present, microalgae have been commercially cultivated only to obtain valuable products like carotenoids ( $\beta$-carotene and astaxanthin) and long-chain polyunsatured fatty acids (Hannon et al., 2010). The main challenge that the algae biofuels sector is facing is to reduce capital and operating costs and so far only few studies have suggested the development of biodiesel production from microalgae on a commercial scale (Brentner et al., 2011; Sevigné Itoiz et al., 2012).

Cultivation of microalgae can be done in open systems (lakes, ponds) or in controlled closed systems called photobioreactors (PBRs). Open ponds and lagoons have lower costs but also suffer from low productivity and contamination problems. PBRs enhance productivity, avoid cultivation contamination and are more reliable but they have high capital construction and operating costs (Demirbas, 2010; Benson et al., 2014). In both open and closed systems, there is a high energy requirement for mixing water with nutrients and $\mathrm{CO}_{2}$ during the cultivation stage (Rodolfi et al., 2009). Moreover, harvesting and dewatering of biomass lead to high costs for production facilities as well as a high energy use (Brennan and Owende, 2013).

As part of the increasing research activities on algal biofuels, several Life Cycle al., 2009; Khoo et al., 2011; Holma et al., 2013).

109 This study takes origin in the encouraging results obtained by Brentner et al., 2011 on 110 flat panel PBRs hypothetically located in Phoenix, AZ. The location of PBRs has been 
111 moved to Denmark, and a variety of technologies and implementation strategies to

112 produce biodiesel from microalgae has been analyzed. Some of these technologies

113 have already been developed on an industrial scale to produce valuable algal

114 compounds while others are still on an experimental laboratory scale. Combing through

115 different technologies in the different production stages, a total of 24 scenarios have

116 been created. The energy demand and GHG emissions of the 24 scenarios and of the

117 fossil diesel have been benchmarked and compared using a 'well-to-tank' life cycle

118 approach. The sensitivity of some parameters that could affect biodiesel production

119 have been evaluated.

120

1212 Material and methods

122 This study applies Life Cycle Assessment (LCA) to evaluate the environmental 123 performance of the different scenarios. LCA quantifies the environmental impacts of a 124 product system considering its entire life cycle and is standardized by ISO $12514040 / 14044$ (ISO, 2006a and 2006b). The method has four phases: goal and scope 126 definition, life cycle inventory (LCI), life cycle impact assessment (LCIA), and 127 interpretation of results. Below, data used and approaches applied in each of these 128 phases are described.

\subsection{Goal and scope definition}

130 The goal of this LCA study was to assess algal biodiesel production on a hypothetical 131 commercial scale by analyzing and comparing both consolidated (from algae-based 132 industry) and pioneering technologies, focusing on strengths and weaknesses which 133 influence the performance.

134 Assuming $39.35 \mathrm{MJ} / \mathrm{kg}$ as high heating value (HHV) (Brentner et al., 2011), the 135 functional unit was $1 \mathrm{MJ}$ of biodiesel and the system boundaries were 'well-to-tank' (i.e. 136 from cultivation to biodiesel storage). The stages included were (Fig. 1): cultivation, 
137 harvesting, drying, oil extraction, transesterification, anaerobic digestion of residual

138 biomass with subsequent biogas combustion to generate energy (Zhang et al., 2013),

139 and use of the by-product glycerol for the synthesis of propylene glycol. Substitution by

140 system expansion was considered for biogas production and glycerol use. Substitution

141 of glycerol in the production of propylene glycol has been chosen since this use is

142 claimed to be the most economically attractive within the chemical industry (Pagliaro

143 and Rossi, 2010). The algae selected was Nannochloropsis cultivated in flat panel

144 PBRs and the production was assumed to be located in Denmark. Manufacturing,

145 facilities maintenance, and use of infrastructures were not taken into account, except

146 for the materials used for PBRs. The PBRs manufacturing is included since Sevigné-

147 Itoiz et al. (2012) state that construction of PBRs contributes significantly to energy use

148 and environmental impacts. On the other hand, Brentner et al. (2011), who included

149 also construction materials in the assessment, find that those materials contribute less

150 than $1 \%$ to the cumulative energy demand (CED). The biodiesel combustion is not

151 included by system boundaries.

$152 \quad 2.2$ Life cycle inventory (LCI)

153 All main inventory data are shown in Table 1. As indicated most of the data were

154 compiled from previous works and were adapted to a Danish scenario (Table 2). The

155 databases used for obtaining the additional process data were Gabi Professional 2006

156 (PE International, 2007) and Ecoinvent 2.2 (Ecoinvent Centre, 2007).

$157 \quad 2.2 .1$ Scenarios

158 A summary of the cultivation system and technologies assumed for each of the 24

159 scenarios are reported in Table 3. As shown, cultivation in either freshwater (scenarios

160 from 1 to 6 ) or wastewater (scenarios from 7 to 12) were considered. The algae require

161 an injection of $\mathrm{CO}_{2}$ into the growth medium for optimal growth and each scenario

162 alternatively assumed the use of either pure $\mathrm{CO}_{2}$ (where the carbon dioxide is delivered 
163 in tanks) or waste $\mathrm{CO}_{2}$ (named $\mathrm{wCO}_{2}$, with flue gas pumped from a nearby cement

164 production plant into the PBRs). In the harvesting stage, three techniques were 165 assessed: flocculation with aluminum sulfate (scenarios 1, 4, 7, 10), flocculation with 166 lime (scenarios 2, 5, 8, 11), and centrifugation (scenarios 3, 6, 9, 12). Finally, both 167 hexane extraction (scenarios $1,2,3,7,8,9)$ and $\mathrm{sCO}_{2}$ (supercritical $\mathrm{CO}_{2}$ ) extraction 168 (scenarios $4,5,6,10,11,12$ ) were assessed in the oil extraction stage.

169 Consolidated technologies of the current market (i.e. flocculation, centrifugation, 170 extraction with hexane, algal cultivation in freshwater and with pure $\mathrm{CO}_{2}$ ) have thus 171 been compared with advanced technologies not implemented on large scale (i.e. use of 172 wastewater and waste $\mathrm{CO}_{2}$, and extraction with $\mathrm{sCO}_{2}$ ). The next sections, describe each stage in details.

\subsection{Algal biomass cultivation and harvesting}

Inventory data for cultivation and harvesting are showed in Table 1 and parameters used for modeling the Nannochloropsis cultivation in PBRs are illustrated in Table 4. The wastewater scenarios did not involve synthetic nutrients since wastewater is supposed to contain an adequate amount of nutrients to serve as a suitable growth medium for microalgae (Pittman et al., 2011). The $\mathrm{CO}_{2}$ taken up during algal growth was subtracted from the total amount of $\mathrm{CO}_{2}$ emissions in both 'pure $\mathrm{CO}_{2}$ ' and 'waste $\mathrm{CO}_{2}$ ' scenarios, whereas the $\mathrm{CO}_{2}$ emissions from the production process of pure $\mathrm{CO}_{2}$ are accounted for. The water content of wet algal biomass after harvesting is assumed to be about $70 \%$ 184 (Singh et al., 2012).

\subsection{Drying and algal oil extraction} Inventory data for drying and algal oil extraction are showed in Table 1. Drying stage was only assumed to be a requirement for hexane oil extraction since $\mathrm{sCO}_{2}$ extraction is carried out directly from wet biomass (Xu et al., 2011; Mendes et al., 1995). 
189 We assumed the use of thermal dryers with an energy consumption around 3.3 MJ per

190 kilogram of evaporated water (Xu et al., 2011).

191 A dry biomass content in Nannochloropsis of $29 \%$ lipid, $10 \%$ carbohydrates and $30 \%$ 192 proteins is hypothesized (Rodolfi et al., 2009; Razon and Tan, 2011). According to 193 Brentner et al. (2011), the extraction efficiency with hexane is assumed to be 0.91 .

194 Supercritical $\mathrm{CO}_{2}$ for algal lipids extraction has been applied in laboratory on a number 195 of algal species: Skeletonema costatum and Ochromonas danica (Polak et al., 1989), 196 Chlorella vulgaris (Mendes et al., 1995), Botryococcus braunii, Dunaliella salina, 197 Arthrospira maxima (Mendes et al., 2003), Haematococcus pluvialis (Thana et al., 198 2008). Recently, experiments have also been started on Nannochloropsis sp. (Andrich 199 et al., 2005; Douglas, 2011; Crampon et al., 2013) but little information is reported on 200 extraction efficiency even if the authors analyze the effects of operating conditions on 201 the kinetics of the supercritical fluid extraction (Andrich et al., 2005; Crampon et al., 202 2013; Baskette, 2015). In scenarios assuming extraction with supercritical $\mathrm{CO}_{2}, 27.5$ $203 \mathrm{MPa}$ and $47.5^{\circ} \mathrm{C}$ were chosen as operating conditions (Mendes et al., 1995) and the 204 extraction efficiency is assumed to be equal to the one with hexane (0.91). Neither 205 hexane nor $\mathrm{CO}_{2}$ recycling were considered in the $\mathrm{LCl}$ analysis.

2062.5 Transesterification and use of glycerol

207 The amount of electricity and heat used in transesterification stage are shown in Table 208 1. The conversion efficiency was hypothesized 98\% (Brentner et al., 2011) and the catalyst used was methanol. The avoided production of propylene oxide has been calculated on the basis of the stoichiometric ratio and the process yields of the involved

211 reactions. Data for propylene oxide to propylene glycol were from Ecoinvent 2.2

212 (Ecoinvent Centre, 2007), data for glycerol to propylene glycol were from Pagliaro et al. 213 (2007); the yields were 95\% and 73\%, respectively. 


\subsection{Life cycle impact assessment (LCIA)}

The LCIA method applied was IMPACT 2002+ which proposes a feasible implementation of a combined midpoint/damage approach (Humbert et al., 2012). The chosen impact categories have been: global warming potential (GWP) and nonrenewable energy consumption. For each scenario, the performances of algal biodiesel were compared with those of fossil diesel (from Ecoinvent 2.2; Ecoinvent Centre, 2007).

\subsection{Sensitivity analysis}

The sensitivity analysis estimates the influence of assumptions, i.e. changes in input parameters, on the model outcome (ISO, 2006a; ISO, 2006b). Among all the possible parameters to be considered for the sensitivity analysis, we have selected two. The first parameter is the extraction efficiency ranging from 0.91 in the Base case (extraction efficiency with hexane, Brentner et al., 2011) to 0.95 in the Case 1 (extraction efficiency with supercritical $\mathrm{CO}_{2}$, Brentner et al., 2011).

The second parameter considered is the lipid content in the algal biomass which can vary dramatically as a result of the nitrogen supply (Jorquera et al., 2010; Khoo et al., 2011; Razon and Tan, 2011). The considered range of lipid content varies from $29 \%$ (lipid content experimentally observed in standard conditions by Rodolfi et al., 2009) to $60 \%$ (lipid content experimentally observed under nitrogen deprivation conditions by Rodolfi et al., 2009).

\section{Results and discussion}

The results generally show that 'pure' $\mathrm{CO}_{2}$ (grey columns, Fig.2 and Fig.3) causes GHG emissions and energy consumption at least 25\%-30\% higher than waste $\mathrm{CO}_{2}$ (white columns, Fig.2 and Fig.3). This agrees well with the results obtained by Borkowski et al. (2012) which demonstrated that the use of waste $\mathrm{CO}_{2}$ for algae 
240 cultivation in PBR from a nearby power plant decreased GHG emissions by about $50 \%$

241 compared to the use of 'pure' $\mathrm{CO}_{2}$.

242 In general, GWP of biodiesel scenarios is one order of magnitude higher than GWP of

243 fossil diesels (black column, Fig.2). Only the last three scenarios $\left(\mathrm{Sc} 10-\mathrm{wCO}_{2}, \mathrm{Sc11-}\right.$ $244 \mathrm{wCO}_{2}$ and $\mathrm{Sc} 12-\mathrm{wCO}_{2}$ ) show $\mathrm{GHG}$ emissions similar to or lower than those of fossil 245 diesel. The last three scenarios achieve the best performances also considering non246 renewable energy consumption (Fig. 3), even if this is considerably higher compared to 247 fossil diesel. This indicates that the coupling of the 'waste flows' for algal cultivation 248 with the use of $\mathrm{sCO}_{2}$ for algal oil extraction - that avoids the drying stage - could be an 249 interesting production system. The best scenario is $\mathrm{Sc} 10-\mathrm{wCO}_{2}$ (flocculation with 250 aluminum sulphate) which shows a negative GWP indicating a GHG sequestration and the lowest energy consumption. The result is in accordance with the studies by Lardon et al. (2009) which observed that only wet extraction can save GHG emissions in algal biodiesel production and by Vasudevan et al. (2012) which calculated very low GHG emissions $\left(0.053 \mathrm{~kg}\right.$ of $\mathrm{CO}_{2}$ eq/MJ) when wet extraction was applied. Also Xu et al. (2011) observed that wet extraction dramatically decreases energy consumption. Interesting information is provided by the 'non-renewable energy investment in energy delivered' (NEIED) (Yang and Chen, 2012). NEIED is expressed as the ratio between the non-renewable energy used directly and indirectly in the production process and the energy content in the biofuel. In this study the NEIED is $>1$ in all 24 scenarios. In

260 particular, in our simulations algal biodiesel production requires from $20 \mathrm{MJ}$ (Sc10$\left.\mathrm{wCO}_{2}\right)$ to $90 \mathrm{MJ}\left(\mathrm{Sc} 3-\mathrm{CO}_{2}\right)$ for producing $1 \mathrm{MJ}$ of biodiesel. These values are very high but comparable with results obtained by other authors. Jorquera et al. (2010) find a consumption of about $14 \mathrm{MJ} / \mathrm{MJ}$ for tubular PBRs including only cultivation stage and Sevigné Itoiz et al. (2012) report a consumption of $901 \mathrm{MJ} / \mathrm{kg}$ of DW biomass for indoor PBRs. In fact, cultivation in PBRs has a large energy demand due to the $\mathrm{CO}_{2}$ pumping and nutrients mixing (Weinberg et al., 2012; Borkowski et al., 2012; Khoo et al., 2011). 
267 Below we evaluate the relative contributions to GWP and non-renewable energy 268 consumption of each stage in the worst $\left(\mathrm{Sc} 3-\mathrm{CO}_{2}\right)$ and the best scenarios (Sc10$269 \mathrm{wCO}_{2}$ ). The stages analyzed are: 1) algae cultivation; 2) harvesting; 3) (drying and) oil 270 extraction; 4) transesterification; 5) anaerobic digestion (of residual biomass) and 6) 271 use of glycerol.

272 Figure 4 illustrates the relative contributions in the worst scenario. As shown, the 273 cultivation stage has the highest contribution to GWP and non-renewable energy 274 consumption (62\% and $66 \%$, respectively), followed by drying and oil extraction ( $23 \%$ 275 and $24 \%$, respectively) and harvesting through centrifugation (15\% and $13 \%$, respectively). Anaerobic digestion contributes by avoiding GHG emissions and nonrenewable energy consumption (both about $-2 \%$ ) while transesterification and use of glycerol in the propylene oxide industry do not give a relevant contribution. These results completely agree with previous studies. Many authors observed that cultivation

280 (Batan et al., 2010; Borkowski et al., 2012; Weinberg et al., 2012), drying (Razon and 281 Tan, 2011; Xu et al., 2011) and lipid extraction (Khoo et al., 2011) were the most 282 impacting stages for biodiesel production both in terms of GHG emissions and energy 283 requirements.

284 Figure 5 illustrates the best scenario. As far as GWP concerns, cultivation (-40\%) and anaerobic digestion (-25\%) contribute by avoiding GHG emissions while the most 286 impacting stages are harvesting (15\%) and $\mathrm{sCO}_{2}$ extraction (15\%). Transesterification 287 and the glycerol use are negligible. Regarding non-renewable energy consumption, the most significant process is algae cultivation (92\%) while the other stages have a very low contribution. The negative contribution of cultivation on GHG emissions is due to the sequestration of $\mathrm{CO}_{2}$ in the algal cells and to the use of wastewater which eliminate the need of fertilizer production. However, these improvements do not eliminate the need of electric power during the cultivation stage. As a final result, in the best-case scenario we have an increment of the cultivation stage contribution to the energy 
294 consumption. This is due to the fact that the energy demand of the algal harvesting and

295 lipid extraction stages decreases in comparison to the worst case.

297 The percentage contribution analysis has identified three stages as the bottlenecks of algal biodiesel production: cultivation, drying and oil extraction, and harvesting. Regarding the cultivation stage, the contribution of the different processes to the environmental impact are detailed in the Supplementary Data, figures 2.1, 2.2, 2.3 and 2.4. Electricity is always a significant contributor and when 'pure' $\mathrm{CO}_{2}$ and/or nutrients are required these contribute significantly as well. The contributions of nutrients, $\mathrm{CO}_{2}$, and electricity vary for the different scenarios. Contributions from construction materials, low density polyethylene (LDPE) sheets and reinforcing steel, are always negligible. Considering the performances of Sc10-wCO, $\mathrm{Sc}_{21}-\mathrm{wCO}_{2}$ and $\mathrm{Sc} 12-\mathrm{wCO}_{2}$ scenarios, it is evident that the capability to cultivate algae using waste flows (aqueous and gaseous) plays a fundamental role for an environmental beneficial development of large scale biodiesel production from microalgae. Anyway, these technologies need to be improved further to become efficient, affordable and accessible. Currently, the cultivation of algae in wastewater has not been developed on commercial scale yet but only on pilot plants. Several challenges exists, e.g. the high turbidity of wastewater restricting the light penetration and making the algal cultivation inefficient (Pedroni et al., 2001). Therefore, a water clarification pre-treatment could be necessary in order to reduce the presence of suspended matter and organic load (Pedroni et al., 2001). Also the use of waste $\mathrm{CO}_{2}$ is still experimental on a pilot scale. The main issues to be solved are the transfer of waste flue gas from an industrial plant to PBRs and the $\mathrm{CO}_{2}$ losses during this transfer. In fact, the energy demand for pumping the flue gas and the distance from the plant to PBRs limit this transfer (Pedroni et al., 2001). Moreover, it is challenging to control the $\mathrm{O}_{2}$-concentration and the temperature which has to be reduced from above $100^{\circ} \mathrm{C}$ to app. $2^{\circ} \mathrm{C}$ (Dorminey, 20 13). Additionally, flue gases 
321 contain pollutants such as $\mathrm{NOx}$ and $\mathrm{SO}_{2}$ which may have adverse effects on the algal

322 species. However, first findings from studies reveal that the presence of pollutants in

323 the flue gas in today's industrial emissions seems to be less of a problem in relation to

324 the growth of the algae (Mortensen and Gislerød, 2014).

326 The drying and oil extraction stage is the second relevant bottleneck. Oil extraction with

327 the $\mathrm{sCO}_{2}$-process decreases the impact contribution because it does not require drying

328 of the algal biomass. Also in this case, the 'key' technology is very innovative and must

329 be further enhanced. Mendes et al. (1995) observed that higher pressures and

330 temperatures led to higher efficiencies in the extraction of lipids but Santana et al.

331 (2012) found a correlation between the pressure and the presence of unsaturated

332 compounds, i.e. high pressure leads to high amounts of unsaturated compounds in the algal oil thus reducing the biodiesel quality.

In terms of energy consumption and GHG emissions, the harvesting stage also played a significant role. In general, flocculation requires less energy than centrifugation; in particular, Nannochloropsis centrifugation has a large energy demand due to the small size of the cells (Rodolfi et al., 2009). This in line with Sander and Murthy (2010) who also identified a high energy demand of centrifugation (50\% higher than flocculation) in

340 comparison to other algal harvesting technologies such as separation or filtration.

341 Flocculation with aluminum sulphate (scenarios 1, 4, 7, 10) and with lime (scenarios 2,

$3425,8,11)$ show similar GHG emissions and energy performances, see Fig. 2 and Fig. 3.

343 However, although flocculation requires less energy than centrifugation, both

344 flocculants present some disadvantages. The main product of flocculation with 345 aluminum sulphate is aluminum hydroxide which forms aggregates with algal biomass 346 rendering it toxic for methanogens during anaerobic digestion (Demirbas, 2010). Even 
347 if lime is less toxic than aluminum sulphate, it is less used for flocculation due to the

348 precipitate formation, i.e. $\mathrm{CaCO}_{3}$, in the water (Pedroni et al., 2001).

349 A possible improvement with respect to both flocculation and centrifugation could be

350 the development of bio-flocculation (Pedroni et al., 2001). Bio-flocculation is biologically

351 induced by bacteria (Lee et al., 2009). Recently, a naturally flocculating diatom

352 Skeletonema was used to form flocs of Nannochloropsis (Schenk et al., 2008). Bio-

353 flocculation is not toxic for microalgae, it requires low operating costs, and has a low

354 energy demand. However, bio-flocculation is affected by environmental conditions

355 which are the most relevant aspects to improve (Schenk et al., 2008).

\section{Sensitivity analysis}

357 Tables $5 \mathrm{~A}$ and $5 \mathrm{~B}$ present the results of the sensitivity analysis. Increasing extraction 358 efficiency from 0.91 to 0.95 , results in lower values for GWP and non-renewable 359 energy consumption (about $5 \%$ less than Basic Case).

360 Likewise, increasing the lipid content from $29 \%$ to $60 \%$ reduces both GHG emissions and energy consumption by app. 50\%. Therefore, lipid content was confirmed as an important parameter for biodiesel production. Nonetheless, even with high lipid content the energy and GHG emissions performances of algal biodiesel are still inferior to those of diesel from fossil sources. These results are in agreement with the observation of Khoo et al. (2011) and Razon and Tan (2011). In particular, Khoo et al. (2011) demonstrated that increasing the lipid content by about $10 \%$ and $20 \%$ decreased the energy consumption by about $4 \%$ and $6 \%$, respectively.

\section{Conclusion}

369 Algal biodiesel produced through current conventional technologies shows higher 370 energy demand and GHG emissions than those of fossil diesel. 'Wastewater scenarios' 371 coupled with waste $\mathrm{CO}_{2}$ have the lowest impact in GHG-emissions and non-renewable 372 energy consumption, in some cases even better than fossil diesel in terms of GHG- 
373 emissions. However, a positive energy balance is still far from being achieved by algal

374 biodiesel. Thus, further improvements are required in order to achieve a beneficial development of biodiesel production on an industrial scale. In particular, different aspects of cultivation need to be enhanced, such as the use of wastewater as source of nutrient and $\mathrm{CO}_{2}$-rich flue gas from industrial power plants as source of carbon. The research has been addressed towards algae cultivation with 'waste flows', that seems to be the key to reduce both the demand of energy and the GHG-emissions of biodiesel from microalgae. Additionally, the energy demand for mixing, pumping, etc. of the cultivation stage should be dramatically decreased. Considering the extraction, supercritical $\mathrm{CO}_{2}$ extraction appears to be an interesting technology. However, further studies are needed to address the main limitations; how to achieve high temperatures and high pressures and still avoiding the formation of unsaturated compounds.

\section{Acknowledgments}

The authors wish to thank Prof. Rossella Pistocchi, Dr. Giulia Samorì and Dr. Laura Pezzolesi of 'CIRI Energia e Ambiente' of University of Bologna for the information about characteristics and cultivation of Nannochloropsis. The authors also thank Prof. Morten Birkved (DTU Management, QSA) for his support during the development of the model.

\section{References}

Aitken, D., Bulboa, C., Godoy-Faundez, A., Turrion-Gomez, J.L., Antizar-Ladislao, B., 2014. Life cycle assessment of macroalgae cultivation and processing for biofuel production. J. Clean. Prod. 75, 45-56. 
397 Andrich, G., Nesti, U., Venturi, F., Zinnai, A., Fiorentini, R., 2005. Supercritical fluid

398 extraction of bioactive lipids from the microalga Nannochloropsis sp. Eur. J. Lipid Sci.

399 Technol. 107, 381-386.

400 Batan, L., Quinn, J., Willson, B., Bradley, T., 2010. Net energy and greenhouse gas

401 emission evaluation of biodiesel derived from microalgae. Environ. Sci. Technol. 44, $402 \quad 7975-7980$.

403 Benson, D., Kerry, K., Malin, G., 2014. Algal biofuels: impact significance and 404 implications for EU multi-level governance. J. Clean. Prod. 72, 4-13.

405 Borkowski, M.G., Zaimes, G.G., Khanna, V., 2012. Integrating LCA and thermodynamic 406 analysis for sustainability assessment of algal biodiesel. Sustainable Systems and 407 Technology (ISSST). Proceedings of IEEE International Symposium. Boston, $16^{\text {th }}-18^{\text {th }}$ 408 May 2012.

409 Brentner, L.B., Eckelman, M.J., Zimmerman, J.B., 2011. Combinatorial Life Cycle 410 Assessment to inform process design of industrial production of algal biodiesel. 411 Environ. Sci. Technol. 45, 7060-7067.

412 Brennan, L., Owende, P., 2013. Biofuels from microalgae: towards meeting advanced 413 fuel standards, in: Lee, W.J. (Ed.), Advanced Biofuels and Bioproducts. Springer, New 414 York, pp. 553-599.

415 Clarens, A.F., Resurreccion, E.P., White, M.A., Colosi, L.M., 2010. Environmental life 416 cycle comparison of algae to other bioenergy feedstocks. Environ. Sci. Technol. 44, $417 \quad 1813-1819$.

418 Crampon, C., Mouahid, A., Toudji, S.A., Lépine, O., Badens, E., 2013. Influence of 419 pretreatment on supercritical CO2 extraction from Nannochloropsis oculata. J. 420 Supercrit. Fluid. 79, 337-344.

421 Demirbas, A., 2010. Use of algae as a biofuel sources. Energ. Convers. Manage. 51, 422 2738-2749. 
423 Demirbas, A., 2011. Biofuels from algae for sustainable development. Appl. Energ. 88,

$424 \quad 3473-3480$.

425 Douglas, N., 2011. Extract characteristics of supercritical carbon dioxide extraction of

426 Nannochloropsis oculata. Thesis, Colorado State University, pp. 89.

427 Ecoinvent centre, 2007. Ecoinvent Data and Reports v2.0 Final Reports Ecoinvent 428 2000. Swiss Centre for Life Cycle Inventories, Dübendorf, Switerland.

429 European Commission, 2009. Directive 2009/28/EC of the European Parliament and of 430 the Council of 23 April 2009 on the promotion of the use of energy from renewable 431 sources and amending and subsequently repealing Directives 2001/77/EC and 432 2003/30/EC. Official Journal of the European Union, Volume 52, 5 June 2009.

433 Festel, G., Würmseher, M., Rammer, C., Boles, E., Bellof., 2014. Modelling production 434 cost scenarios for biofuels and fossil fuels in Europe. J. Clean. Prod. 66, 242-253.

435 Foley, P.M., Beach, E.S., Zimmerman, J.B., 2011. Algae as a source of renewable 436 chemicals: opportunities and challenges. Green Chem. 13, 1399-1405.

437 Grima, E.M., Belarbi, E.H., Acien Fernandez, F.G., Robles Medina, A., Chisti, Y., 2003.

438 Recovery of microalgal biomass and metabolites: process options and economics.

439 Biotechnol. Adv. 20, 491-515.

440 Grobbelaar, J.U., 2004. Algal nutrition, in: Richmond, A. (Ed.), Handbook of microalgal 441 culture: biotechnology and applied phycology. Blackwell Publishing Ltd., Oxford, pp. $44297-115$.

443 Hannon, M., Gimpel, J., Tran, M., Rasala, B., Mayfield, S., 2010. Biofuels from algae: 444 challenges and potential. Biofuels. 5, 763-784.

445 Holma, A., Koponen, K., Antikainen, R., Lardon, L., Leskinen, P., Roux, P., 2013. 446 Current limits of life cycle assessment framework in evaluating environmental 447 sustainability e case of two evolving biofuel technologies. J. Clean. Prod. 54, 215-228.

448 Humbert S., De Schryver A., Bengoa X., Margni M., Jolliet O., 2012. IMPACT 2002+: 449 User guide. 
450 ISO 2006a. Environmental Management-Life Cycle Assessment-Principles and

451 Framework, second ed., ISO 14040; 2006-07-01; ISO: Geneva, Switzerland.

452 ISO, 2006b. Environmental Management-Life Cycle Assessment-Requirements and 453 Guidelines, first ed., ISO 14040; 2006-07-01; ISO: Geneva, Switzerland.

454 Jorquera, O., Kiperstok, A., Sales, E.A., Embiruçu, M., Ghirardi, M.L., 2010. 455 Comparative energy life-cycle analyses of microalgal biomass production in open 456 ponds and photobioreactors. Bioresource Technol. 101, 1406-1413.

457 Khoo, H.H., Sharratt, P.N., Das, P., Balasubramanian, R.K., Naraharisetti, P.K., Shaik, 458 S., 2011. Life cycle energy and $\mathrm{CO}_{2}$ analysis of microalgae-to-biodiesel: Preliminary results and comparisons. Bioresource Technol. 102, 5800-5807.

460 Kumar, A., Ergas, S., Yuan, X., Sahu, A., Zhang, Q., Dewulf, J., Malcata, F. X., Van Langenhove, $\mathrm{H} .$, 2010. Enhanced $\mathrm{CO}_{2}$ fixation and biofuel production via microalgae: recent developments and future directions. Trends Biotechnol. 28, 371-380.

463 Lardon, L., Helias, A., Sialve, B., Steyer, J. P., Bernard, O., 2009. Life Cycle 464 Assessment of Biodiesel Production from Microalgae. Environ. Sci. Technol. 43, 64754656481.

466 Lee, A.K., Lewis, D.M., Ashman, P.J., 2009. Microbial flocculation, a potentially low467 cost harvesting technique for marine microalgae for the production of biodiesel. J. Appl. 468 Phycol. 21, 559-567.

469 Liew, W.H., Hassim, M.H., Ng, D.K.S., 2014. Review of evolution, technology and 470 sustainability assessments of biofuel production. J. Clean. Prod. 71, 11-29.

471 Lü, J., Sheahan, C., Fu, P., 2011. Metabolic engineering of algae for fourth generation 472 biofuels production. Energy Environ. Sci. 4, 2451-2466.

473 Mendes, R.L., Fernandes, H.L., Coelho, J.P., Reis, E.C., Cabral, J.M.S., Novais, J.M., 474 Palavra, A.F., 1995. Supercritical $\mathrm{CO}_{2}$ extraction of carotenoids and other lipids from 475 Chlorella vulgaris. Food Chem. 53, 99-103. 
476 Mendes, R.L., Nobre, B.P., Cardoso, M.P., Pereira, A.P., Palavra, A.F., 2003.

477 Supercritical carbon dioxide extraction of compounds with pharmaceutical importance

478 from microalgae. Inorg. Chim. Acta. 356, 328-334.

479 Mortensen, L.M., Gislerød, H.R., 2014. The effect on growth of Chlamydomonas 480 reinhardtii of flue gas from a power plant based on waste combustion. AMB Express, 4, $481 \quad 49-54$.

482 Pagliaro, M., Ciriminna, R., Kimura, H., Rossi, M., Della Pina, C., 2007. From Glycerol 483 to value-added products. Angew. Chem. Int. Edit. 46, 4434-4440.

484 Pagliaro, R., Rossi, M., 2010. Future of Glycerol: 2nd Edition. Royal Society of 485 Chemistry, London, UK.

486 Pedroni, P., Davison, J., Beckert, H., Bergman, P., Benemann, J., 2001. A proposal to 487 establish an international network on biofixation of $\mathrm{CO} 2$ and greenhouse gas 488 abatement with microalgae. J. Energy Environ. Res. 1, 136-150.

489 PE International, 2007. GaBi Professional Database. http://documentation.gabi490 software.com (accessed October 2013).

491 Pittman, J.K., Dean, A.P., Osundeko, O., 2011. The potential of sustainable algal 492 biofuel production using wastewater resources. Bioresource Technol. 102, 17-25.

493 Polak, J.T., Balaban, M., Peplow, A., Philips, A.J., 1989. Supercritical carbon dioxide 494 extraction of lipids from algae, in: Johnston, K.P., Penninger, J.M.L. (Eds.), ACS 495 Symposium Series:406. Supercritical Fluid Science and Technology. American 496 Chemical Society, Washington D.C., pp. 449-467.

497 Razon, L.F., Tan, R.R., 2011. Net energy analysis of the production of biodiesel and 498 biogas from the microalgae: Haematococcus pluvialis and Nannochloropsis sp.. Appl. 499 Energ. 88, 3507-3514.

500 Ribeiro, K.S., Kobayashi, S., Beuthe, M., Gasca, J., Greene, D., Lee, D.S., Muromachi, 501 Y., Newton, P.J., Plotkin, S., Sperling, D., Wit, R., Zhou, P.J., 2007. Transport and its 502 infrastructure. In Climate Change 2007: Mitigation. Contribution of Working Group III to 
503 the Fourth Assessment Report of the Intergovernmental Panel on Climate Change [B.

504 Metz, O.R. Davidson, P.R. Bosch, R. Dave, L.A. Meyer (eds)], Cambridge University

505 Press, Cambridge, United Kingdom and New York, NY, USA.

506 Rodolfi, L., Chini Zittelli, G., Bassi, N., Padovani, G., Biondi, N., Bonini, G., Tredici, M.

507 R., 2009. Microalgae for Oil: Strain Selection, Induction of Lipid Synthesis and Outdoor

508 Mass Cultivation in a Low-Cost Photobioreactor. Biotechnol. Bioeng. 102, 100-112.

509 Sander, K., Murthy, G.S., 2010. Life cycle analysis of algal biodiesel. Int. J. Life Cycle

$510 \quad$ Assess. 15, 704-714.

511 Santana, A., Jesus, S., Larrayoz, M. A., Filho, R. M., 2012. Supercritical carbon dioxide

512 extraction of algal lipids for the biodiesel production. Procedia Eng. 42, 1755-1761.

513 Schenk, P.M., Thomas-Hall, S.R., Stephens, E., Marx, U., Mussgnug, J.H., Posten, C.,

514 Kruse, O., Hankamer, B., 2008. Second generation biofuels: high-efficiency microalgae

515 for biodiesel production. Bioenerg. Res. 1, 20-43.

516 Scott, S.A., Davey, M.P., Dennis, J.S., Horst, I., Howe, C.J., Smith, D.J.L., Smith, A.G., 517 2010. Biodiesel from algae: challenges and prospects. Curr. Opin. Biotech. 21, 277518286.

519 Sevigné-Itoiz, E., Fuentes-Grunewald, C., Gasol, C. M., Garces, E., Alacid, E., Rossi, 520 S., Rieradevall, J., 2012. Energy balance and environmental impact analysis of marine 521 microalgal biomass production for biodiesel generation in a photobioreactor pilot plant.

522 Biomass. Bioenerg. 39, 324-335.

523 Singh, A., Nigam, P.S., Murphy, J.D., 2011. Mechanism and challenges in 524 commercialisation of algal biofuels. Bioresour. Technol. 102, 26-34.

525 Singh, A., Pant, D., Olsen, S.I., Nigam, P.S, 2012. Key issues to consider in microalgae 526 based biodiesel production. Int. J. Energ. Res. 29, 687-700.

527 Singh, A., Olsen, S.I., 2012. Comparison of algal biodiesel production pathways using 528 Life Cycle Assessment tool, in: Singh, A., Pant, D., Olsen, S.I. (Eds.), Life Cycle 529 Assessment of Renewable Energy Sources. Springer-Verlag, London, pp. 145-168. 
530 Thana, P., Machmudah, S., Goto, M., Sasaki, M., Pavasanta, P., Shotipruka, A., 2008.

531 Response surface methodology to supercritical carbon dioxide extraction of

532 astaxanthin from Haematococcus pluvialis. Bioresour. Technol. 99, 3110-3115.

533 Vasudevan, V., Stratton, R. W., Pearlson, M. N., Jersey, G. R., Beyene, A. G.,

534 Weissman, J. C., Rubino, M., Hileman, J. I., 2012. Environmental Performance of Algal

535 Biofuel Technology Options. Environ. Sci. Technol. 46, 2451-2459.

536 Weinberg, J., Kaltschmitt, M., Wilhelm, C., 2012. Analysis of greenhouse gas

537 emissions from microalgae-based biofuels. Biomass Conv. Bioref. 2, 179-194.

538 Wijffels, R.H, Barbosa, M.J., 2010. An outlook on microalgal biofuels. Science. 329, $539796-799$.

540 Xu, L., Brilman, D.W.F., Withag, J.A.M., Brem, G., Kersten, S., 2011. Assessment of a 541 dry and a wet route for the production of biofuels from microalgae: Energy balance 542 analysis. Bioresour. Technol. 102, 5113-5122.

543 Yang, Q., Chen, G.Q., 2012. Nonrenewable energy cost of corn-ethanol in China.

544 Energ. Policy. 41, 340-347.

545 Zhang, L.X., Wang, C.B., Song, B., 2013. Carbon emission reduction potential of a 546 typical household biogas system in rural China. J. Clean. Prod. 47, 415-421.

$548 \quad$ Web References

549 All-gas, 2012. Available at: http://www.all-gas.eu/Pages/default.aspx. (accessed $550 \quad 15.03 .2015)$.

551 Baskette, R., 2015. Supercritical carbon dioxide extraction of microalgae oils for

552 biodiesel production. Supercritical Fluid Technologies, INC. Available at:

553 http://www.supercriticalfluids.com/wp-content/uploads/TN-115-Supercritical-Carbon-

554 Dioxide-Extraction-of-Microalgae-Oils-for-Biodiesel-Production.pdf (accessed 555 15.03.2015). 
556 BFS Bio Fuel Systems. Available at: http://www.biopetroleo.com/. (accessed

$557 \quad 15.03 .2015)$.

558 Biofuel.org.uk, 2010. Third Generation Biofuels. Available at: http://biofuel.org.uk/third-

559 generation-biofuels.html (accessed 15.07.2015).

560 Danish Meteorological Institute, 2013. Available at: http://www.dmi.dk/en/vejr/

$561 \quad$ (accessed 15.03.2015).

562 Dorminey, B., 2013. A new win-win? CO2-eating microalgae as a biofuel feedstock.

563 GENI Global Network Energy Institute. Available at:

564 http://www.geni.org/globalenergy/library/technical-articles/ (accessed 15.03.2015)

565 US EIA (US Energy Information Administration), 2015. International Energy Statistics.

566 Available at: http://www.eia.gov/ ((accessed 15.07.2015).

567 
Table 1

570 Summary of the inventory data for producing $1 \mathrm{MJ}$ of algal biodiesel

$571 \quad(\mathrm{HHV}=39.35 \mathrm{MJ} / \mathrm{kg}$ of biodiesel).

\begin{tabular}{|c|c|c|c|}
\hline FRESHWATER CULTIVATION & AMOUNT & UNIT & NOTES \\
\hline Carbon dioxide & 0.61 & $\mathrm{~kg}$ & Calculated from 1 \\
\hline Tap water & 0.47 & $\mathrm{~m}^{3}$ & Calculated from 2 \\
\hline Electricity consumption & 0.78 & kWh & Calculated from 2 \\
\hline Ammonium nitrate & 0.08 & $\mathrm{~kg}$ & Calculated from 3 \\
\hline Monocalcium phosphate & 0.03 & $\mathrm{~kg}$ & Calculated from 3 \\
\hline \multicolumn{4}{|l|}{ WASTEWATER CULTIVATION } \\
\hline Carbon dioxide & 0.61 & $\mathrm{~kg}$ & Calculated from 1 \\
\hline Wastewater & 0.47 & $\mathrm{~m}^{3}$ & Calculated from 2 \\
\hline Electricity consumption & 0.78 & kWh & Calculated from 2 \\
\hline \multicolumn{4}{|l|}{ FLOCCULATION } \\
\hline Electricity consumption & 0.05 & kWh & Calculated from 2 \\
\hline Aluminium sulphate & 0.04 & $\mathrm{~kg}$ & Calculated from 4 \\
\hline Lime & 0.15 & $\mathrm{~kg}$ & Calculated from 5 \\
\hline \multicolumn{4}{|l|}{ CENTRIFUGATION } \\
\hline Electricity consumption & 0.11 & kWh & Calculated from 6 \\
\hline \multicolumn{4}{|l|}{ DRYING } \\
\hline Heat & 1.12 & MJ & Calculated from 7 \\
\hline \multicolumn{4}{|l|}{ EXTRACTION WITH HEXANE } \\
\hline Electricity consumption & 0.01 & kWh & Calculated from 2 \\
\hline Heat & 0.10 & MJ & Calculated from 2 \\
\hline Hexane & 0.39 & $\mathrm{~g}$ & Calculated from 5 \\
\hline \multicolumn{4}{|l|}{$\begin{array}{l}\text { SUPERCRITICAL } \mathrm{CO}_{2} \\
\text { EXTRACTION }\end{array}$} \\
\hline $\mathrm{CO}_{2}$ liquid & 3.7 & $\mathrm{~g}$ & Calculated from 8 \\
\hline Electricity consumption & 0.18 & kWh & Calculated from 9 \\
\hline \multicolumn{4}{|l|}{ TRANSESTERIFICATION } \\
\hline Electricity consumption & 0.001 & kWh & Calculated from 2 \\
\hline Heat & 0.02 & MJ & Calculated from 2 \\
\hline Methanol & 2.9 & $\mathrm{~g}$ & Calculated from 5 \\
\hline
\end{tabular}

589 1: Wijffels and Barbosa, 2010

590 2: Brentner et al., 2011

591 3: Grobbelaar, 2004

592 4: Grima et al., 2003

593 5: Lardon et al., 2009

594 6: Foley et al., 2011

595 7: Xu et al., 2011

596 8: Mendes et al., 1995

597 9: Singh and Olsen, 2012

598 
599

600 Table 2

601 Parameters and processes used in the study adapted to the Danish situation.

\begin{tabular}{|c|c|c|c|}
\hline PARAMETERS & AMOUNT & UNIT & REFERENCES \\
\hline Denmark's electricity mix & & - & Ecoinvent 2.2 \\
\hline Reference year of electricity mix & 2004 & & Ecoinvent 2.2 \\
\hline Denmark's carbon intensity & 0.2 & $\mathrm{~kg} \mathrm{CO}_{2} / 2005$ US $\$$ & US EIA, 2015 \\
\hline $\begin{array}{l}\text { Average solar irradiation in } \\
\text { Denmark }\end{array}$ & 3730 & $\mathrm{MJ} / \mathrm{m} 2 / \mathrm{y}$ & $\begin{array}{l}\text { Danish Meteorological } \\
\text { Institute, } 2013\end{array}$ \\
\hline Productivity days & 200 & $\mathrm{n}^{\circ}$ & $\begin{array}{l}\text { Danish Meteorological } \\
\text { Institute, } 2013\end{array}$ \\
\hline $\begin{array}{l}\mathrm{CO}_{2} \text { emission from Danish } \\
\text { cement industry }\end{array}$ & 1420067 & $t / y$ & Singh and Olsen, 2012 \\
\hline
\end{tabular}

602

603

604 
606 Table 3

607 Summary of cultivation systems and technologies used for each analysed

608 scenario.

\begin{tabular}{|c|c|c|c|c|}
\hline CODE & $\mathrm{CO}_{2}$ SOURCE & WATER SOURCE & $\begin{array}{c}\text { HARVESTING } \\
\text { MODE }\end{array}$ & $\begin{array}{c}\text { EXTRACTION } \\
\text { MODE }\end{array}$ \\
\hline $\mathrm{Sc} 1-\mathrm{CO}_{2}$ & Pure $\mathrm{CO}_{2}$ & Tap water & Aluminum sulfate & With hexane \\
\hline $\mathrm{Sc} 1-\mathrm{wCO}_{2}$ & Waste $\mathrm{CO}_{2}$ & Tap water & Aluminum sulfate & With hexane \\
\hline $\mathrm{Sc} 2-\mathrm{CO}_{2}$ & Pure $\mathrm{CO}_{2}$ & Tap water & Lime & With hexane \\
\hline $\mathrm{Sc} 2-\mathrm{wCO}_{2}$ & Waste $\mathrm{CO}_{2}$ & Tap water & Lime & With hexane \\
\hline $\mathrm{Sc} 3-\mathrm{CO}_{2}$ & Pure $\mathrm{CO}_{2}$ & Tap water & Centrifugation & With hexane \\
\hline $\mathrm{Sc} 3-\mathrm{wCO}_{2}$ & Waste $\mathrm{CO}_{2}$ & Tap water & Centrifugation & With hexane \\
\hline $\mathrm{Sc} 4-\mathrm{CO}_{2}$ & Pure $\mathrm{CO}_{2}$ & Tap water & Aluminum sulfate & Supercritical $\mathrm{CO}_{2}$ \\
\hline $\mathrm{Sc} 4-\mathrm{wCO}_{2}$ & Waste $\mathrm{CO}_{2}$ & Tap water & Aluminum sulfate & Supercritical $\mathrm{CO}_{2}$ \\
\hline $\mathrm{Sc} 5-\mathrm{CO}_{2}$ & Pure $\mathrm{CO}_{2}$ & Tap water & Lime & Supercritical $\mathrm{CO}_{2}$ \\
\hline $\mathrm{Sc} 5-\mathrm{wCO}_{2}$ & Waste $\mathrm{CO}_{2}$ & Tap water & Lime & Supercritical $\mathrm{CO}_{2}$ \\
\hline $\mathrm{Sc} 6-\mathrm{CO}_{2}$ & Pure $\mathrm{CO}_{2}$ & Tap water & Centrifugation & Supercritical $\mathrm{CO}_{2}$ \\
\hline $\mathrm{Sc} 6-\mathrm{wCO}_{2}$ & Waste $\mathrm{CO}_{2}$ & Tap water & Centrifugation & Supercritical $\mathrm{CO}_{2}$ \\
\hline $\mathrm{Sc} 7-\mathrm{CO}_{2}$ & Pure $\mathrm{CO}_{2}$ & Wastewater & Aluminum sulfate & With hexane \\
\hline $\mathrm{Sc} 7-\mathrm{wCO}_{2}$ & Waste $\mathrm{CO}_{2}$ & Wastewater & Aluminum sulfate & With hexane \\
\hline $\mathrm{Sc} 8-\mathrm{CO}_{2}$ & Pure $\mathrm{CO}_{2}$ & Wastewater & Lime & With hexane \\
\hline $\mathrm{Sc} 8-\mathrm{wCO}_{2}$ & Waste $\mathrm{CO}_{2}$ & Wastewater & Lime & With hexane \\
\hline $\mathrm{Sc} 9-\mathrm{CO}_{2}$ & Pure $\mathrm{CO}_{2}$ & Wastewater & Centrifugation & With hexane \\
\hline $\mathrm{Sc} 9-\mathrm{wCO}_{2}$ & Waste $\mathrm{CO}_{2}$ & Wastewater & Centrifugation & With hexane \\
\hline $\mathrm{Sc} 10-\mathrm{CO}_{2}$ & Pure $\mathrm{CO}_{2}$ & Wastewater & Aluminum sulfate & Supercritical $\mathrm{CO}_{2}$ \\
\hline $\mathrm{Sc} 10-\mathrm{wCO}_{2}$ & Waste $\mathrm{CO}_{2}$ & Wastewater & Aluminum sulfate & Supercritical $\mathrm{CO}_{2}$ \\
\hline $\mathrm{Sc} 11-\mathrm{CO}_{2}$ & Pure $\mathrm{CO}_{2}$ & Wastewater & Lime & Supercritical $\mathrm{CO}_{2}$ \\
\hline $\mathrm{Sc} 11-\mathrm{wCO}_{2}$ & Waste $\mathrm{CO}_{2}$ & Wastewater & Lime & Supercritical $\mathrm{CO}_{2}$ \\
\hline $\mathrm{Sc} 12-\mathrm{CO}_{2}$ & Pure $\mathrm{CO}_{2}$ & Wastewater & Centrifugation & Supercritical $\mathrm{CO}_{2}$ \\
\hline $\mathrm{Sc} 12-\mathrm{wCO}_{2}$ & Waste $\mathrm{CO}_{2}$ & Wastewater & Centrifugation & Supercritical $\mathrm{CO}_{2}$ \\
\hline
\end{tabular}


610

611 Table 4

612 Parameters used for modelling the Nannochloropsis cultivation in PBRs.

\begin{tabular}{l|c|c|c|}
\hline PARAMETERS & AMOUNT & UNIT & REFERENCES \\
\hline $\begin{array}{l}\text { Nannochloropsis } \\
\text { productivity }\end{array}$ & 0.27 & $\mathrm{~kg} / \mathrm{m}^{3} / \mathrm{day}$ & Jorquera et al., 2010 \\
\hline $\begin{array}{l}\text { Biomass productivity } \\
\text { Number of PBR }\end{array}$ & 37.8 & $\mathrm{t} / \mathrm{ha} / \mathrm{year}$ & Singh and Olsen, 2012 \\
\hline PBR lenght & 2667 & per hectare & Brentner et al., 2011 \\
\hline PBR height & 2.5 & $\mathrm{~m}$ & Brentner et al., 2011 \\
\hline PBR thick & 1.5 & $\mathrm{~m}$ & Brentner et al., 2011 \\
\hline PBR volume & 0.070 & $\mathrm{~m}$ & Brentner et al., 2011 \\
\hline Residence time & 0.263 & $\mathrm{~m}^{3}$ & Brentner et al., 2011 \\
\hline Area & 2.6 & days & Brentner et al., 2011 \\
\hline LDPE sheet & 3.75 & $\mathrm{~m}^{2}$ & Brentner et al., 2011 \\
\hline Life time & 0.011 & $\mathrm{~kg} / \mathrm{kg}$ biomass & Brentner et al., 2011 \\
\hline Steel & 50 & years & Brentner et al., 2011 \\
\hline Life time & 0.00085 & $\mathrm{~kg} / \mathrm{kg}$ biomass & Brentner et al., 2011 \\
\hline
\end{tabular}


614

615 Table 5A

616 Results of the sensitivity analysis for GWP (kg CO2-eq). Basic case (91\%

617 extraction efficiency and $29 \%$ lipid content) compared to the increase of

618 extraction efficiency (95\%) and lipid content (60\%). The functional unit is $1 \mathrm{MJ}$

619 of biodiesel.

\begin{tabular}{|c|c|c|c|}
\hline CODE & BASIC CASE & $\begin{array}{l}\text { EXTRACTION } \\
\text { EFFICIENCY 95\% }\end{array}$ & $\begin{array}{l}\text { LIPID CONTENT } \\
60 \%\end{array}$ \\
\hline $\mathrm{Sc} 1-\mathrm{CO}_{2}$ & $5.95 E+00$ & $5.70 \mathrm{E}+00$ & $2.90 \mathrm{E}+00$ \\
\hline $\mathrm{Sc} 1-\mathrm{wCO}_{2}$ & $3.11 \mathrm{E}+00$ & $2.98 \mathrm{E}+00$ & $1.53 \mathrm{E}+00$ \\
\hline $\mathrm{Sc} 2-\mathrm{CO}_{2}$ & $6.23 E+00$ & $5.97 \mathrm{E}+00$ & $3.04 \mathrm{E}+00$ \\
\hline $\mathrm{Sc} 2-\mathrm{wCO}_{2}$ & $3.39 E+00$ & $3.25 E+00$ & $1.67 \mathrm{E}+00$ \\
\hline $\mathrm{Sc} 3-\mathrm{CO}_{2}$ & $6.71 E+00$ & $6.43 E+00$ & $3.28 \mathrm{E}+00$ \\
\hline $\mathrm{Sc} 3-\mathrm{wCO}_{2}$ & $3.88 \mathrm{E}+00$ & $3.72 \mathrm{E}+00$ & $1.90 \mathrm{E}+00$ \\
\hline $\mathrm{Sc} 4-\mathrm{CO}_{2}$ & $4.60 \mathrm{E}+00$ & $4.41 \mathrm{E}+00$ & $2.25 \mathrm{E}+00$ \\
\hline $\mathrm{Sc} 4-\mathrm{wCO}_{2}$ & 1.77E+00 & $1.69 \mathrm{E}+00$ & 8.83E-01 \\
\hline $\mathrm{Sc} 5-\mathrm{CO}_{2}$ & $4.88 \mathrm{E}+00$ & $4.68 \mathrm{E}+00$ & $2.39 \mathrm{E}+00$ \\
\hline $\mathrm{Sc} 5-\mathrm{wCO}_{2}$ & $2.05 E+00$ & $1.96 \mathrm{E}+00$ & $1.02 \mathrm{E}+00$ \\
\hline $\mathrm{Sc} 6-\mathrm{CO}_{2}$ & $5.37 E+00$ & $5.14 \mathrm{E}+00$ & $2.62 \mathrm{E}+00$ \\
\hline $\mathrm{Sc} 6-\mathrm{wCO}_{2}$ & $2.54 \mathrm{E}+00$ & $2.43 \mathrm{E}+00$ & $1.25 \mathrm{E}+00$ \\
\hline $\mathrm{Sc} 7-\mathrm{CO}_{2}$ & $4.01 E+00$ & $3.84 \mathrm{E}+00$ & $1.97 E+00$ \\
\hline $\mathrm{Sc} 7-\mathrm{wCO}_{2}$ & $1.18 \mathrm{E}+00$ & $1.13 \mathrm{E}+00$ & $5.96 \mathrm{E}-01$ \\
\hline $\mathrm{Sc} 8-\mathrm{CO}_{2}$ & $4.29 \mathrm{E}+00$ & $4.11 E+00$ & $2.10 E+00$ \\
\hline $\mathrm{Sc} 8-\mathrm{wCO}_{2}$ & $1.46 \mathrm{E}+00$ & $1.40 \mathrm{E}+00$ & 7.32E-01 \\
\hline $\mathrm{Sc} 9-\mathrm{CO}_{2}$ & $4.78 \mathrm{E}+00$ & $4.58 \mathrm{E}+00$ & $2.34 \mathrm{E}+00$ \\
\hline $\mathrm{Sc} 9-\mathrm{wCO}_{2}$ & $1.94 \mathrm{E}+00$ & $1.86 \mathrm{E}+00$ & 9.67E-01 \\
\hline $\mathrm{Sc} 10-\mathrm{CO}_{2}$ & $2.66 \mathrm{E}+00$ & $2.55 \mathrm{E}+00$ & $1.32 \mathrm{E}+00$ \\
\hline $\mathrm{Sc} 10-\mathrm{wCO}_{2}$ & -1.67E-01 & $-1.60 \mathrm{E}-01$ & $-8.32 \mathrm{E}-02$ \\
\hline $\mathrm{Sc} 11-\mathrm{CO}_{2}$ & $2.94 \mathrm{E}+00$ & $2.82 \mathrm{E}+00$ & $1.45 \mathrm{E}+00$ \\
\hline $\mathrm{Sc} 11-\mathrm{wCO}_{2}$ & 1.13E-01 & $1.08 \mathrm{E}-01$ & $5.61 \mathrm{E}-02$ \\
\hline $\mathrm{Sc} 12-\mathrm{CO}_{2}$ & $3.43 E+00$ & $3.29 \mathrm{E}+00$ & $1.69 \mathrm{E}+00$ \\
\hline $\mathrm{Sc}_{12}-\mathrm{wCO}_{2}$ & $5.99 \mathrm{E}-01$ & $5.74 \mathrm{E}-01$ & $3.02 \mathrm{E}-01$ \\
\hline
\end{tabular}

620

621 
622

623

624 Results of the sensitivity analysis for non-renewable energy consumption (MJ).

625 Basic case (91\% extraction efficiency and $29 \%$ lipid content) compared to the 626 increase of extraction efficiency (95\%) and lipid content (60\%). The functional 627 unit is $1 \mathrm{MJ}$ of biodiesel.

\begin{tabular}{|c|c|c|c|}
\hline CODE & BASIC CASE & $\begin{array}{l}\text { EXTRACTION } \\
\text { EFFICIENCY 95\% }\end{array}$ & $\begin{array}{c}\text { LIPID CONTENT } \\
60 \%\end{array}$ \\
\hline $\mathrm{Sc} 1-\mathrm{CO}_{2}$ & $8.27 \mathrm{E}+01$ & $7.92 \mathrm{E}+01$ & $4.03 \mathrm{E}+01$ \\
\hline $\mathrm{Sc} 1-\mathrm{wCO}_{2}$ & $6.51 E+01$ & $6.24 \mathrm{E}+01$ & $3.18 \mathrm{E}+01$ \\
\hline $\mathrm{Sc} 2-\mathrm{CO}_{2}$ & $8.36 E+01$ & $8.01 E+01$ & $4.08 \mathrm{E}+01$ \\
\hline $\mathrm{Sc} 2-\mathrm{wCO}_{2}$ & $6.60 \mathrm{E}+01$ & $6.33 \mathrm{E}+01$ & $3.23 E+01$ \\
\hline $\mathrm{Sc} 3-\mathrm{CO}_{2}$ & $9.27 E+01$ & $8.88 \mathrm{E}+01$ & $4.52 \mathrm{E}+01$ \\
\hline $\mathrm{Sc} 3-\mathrm{wCO}_{2}$ & $7.51 E+01$ & $7.20 E+01$ & $3.67 \mathrm{E}+01$ \\
\hline $\mathrm{Sc} 4-\mathrm{CO}_{2}$ & $6.26 \mathrm{E}+01$ & $6.00 \mathrm{E}+01$ & $3.06 \mathrm{E}+01$ \\
\hline $\mathrm{Sc} 4-\mathrm{wCO}_{2}$ & $4.50 E+01$ & $4.32 \mathrm{E}+01$ & $2.21 \mathrm{E}+01$ \\
\hline $\mathrm{Sc} 5-\mathrm{CO}_{2}$ & $6.36 \mathrm{E}+01$ & $6.09 \mathrm{E}+01$ & $3.11 \mathrm{E}+01$ \\
\hline $\mathrm{Sc} 5-\mathrm{wCO}_{2}$ & $4.60 \mathrm{E}+01$ & $4.41 E+01$ & $2.26 \mathrm{E}+01$ \\
\hline $\mathrm{Sc} 6-\mathrm{CO}_{2}$ & $7.26 E+01$ & $6.96 \mathrm{E}+01$ & $3.55 E+01$ \\
\hline $\mathrm{Sc} 6-\mathrm{wCO}_{2}$ & $5.51 \mathrm{E}+01$ & $5.28 \mathrm{E}+01$ & $2.70 \mathrm{E}+01$ \\
\hline $\mathrm{Sc} 7-\mathrm{CO}_{2}$ & $5.93 \mathrm{E}+01$ & $5.69 \mathrm{E}+01$ & $2.91 \mathrm{E}+01$ \\
\hline $\mathrm{Sc} 7-\mathrm{wCO}_{2}$ & $4.18 \mathrm{E}+01$ & $4.00 E+01$ & $2.06 \mathrm{E}+01$ \\
\hline $\mathrm{Sc} 8-\mathrm{CO}_{2}$ & $6.03 E+01$ & $5.78 \mathrm{E}+01$ & $2.95 \mathrm{E}+01$ \\
\hline $\mathrm{Sc} 8-\mathrm{wCO}_{2}$ & $4.27 E+01$ & 4.09E+01 & $2.10 \mathrm{E}+01$ \\
\hline $\mathrm{Sc} 9-\mathrm{CO}_{2}$ & $6.94 \mathrm{E}+01$ & $6.65 E+01$ & $3.39 E+01$ \\
\hline $\mathrm{Sc} 9-\mathrm{wCO}_{2}$ & $5.18 \mathrm{E}+01$ & $4.96 \mathrm{E}+01$ & $2.54 \mathrm{E}+01$ \\
\hline $\mathrm{Sc} 10-\mathrm{CO}_{2}$ & $3.93 E+01$ & 3.77E+01 & $1.94 \mathrm{E}+01$ \\
\hline $\mathrm{Sc} 10-\mathrm{wCO}_{2}$ & 2.17E+01 & $2.08 \mathrm{E}+01$ & $1.09 \mathrm{E}+01$ \\
\hline $\mathrm{Sc} 11-\mathrm{CO}_{2}$ & $4.02 E+01$ & $3.86 \mathrm{E}+01$ & $1.98 \mathrm{E}+01$ \\
\hline $\mathrm{Sc} 11-\mathrm{wCO}_{2}$ & $2.26 \mathrm{E}+01$ & 2.17E+01 & $1.13 \mathrm{E}+01$ \\
\hline $\mathrm{Sc} 12-\mathrm{CO}_{2}$ & $4.83 E+01$ & 4.73E+01 & $2.42 \mathrm{E}+01$ \\
\hline $\mathrm{Sc} 12-\mathrm{wCO}_{2}$ & $3.17 E+01$ & $3.04 \mathrm{E}+01$ & $1.57 \mathrm{E}+01$ \\
\hline
\end{tabular}


630

631 Figure captions

632 Fig. 1 System boundaries of biodiesel production and the most important flows

642 Ecoinvent Centre, 2007).

643 Fig. 4 Relative contribution of each stage of the worst scenario, which assumed 644 the use of freshwater and 'pure' $\mathrm{CO}_{2}$ for algae cultivation, centrifugation for 645 algal harvesting and algal oil extraction with hexane. (Read the legend from top 646 to bottom)

647 Fig. 5 Relative contributions of each stage of the best scenario, which assumed 648 the use of wastewater and waste $\mathrm{CO}_{2}$ for algae cultivation, flocculation with 649 aluminium sulphate for algal harvesting and $\mathrm{sCO}_{2}$ extraction in algal oil 650 extraction. (Read the legend from top to bottom) 
652

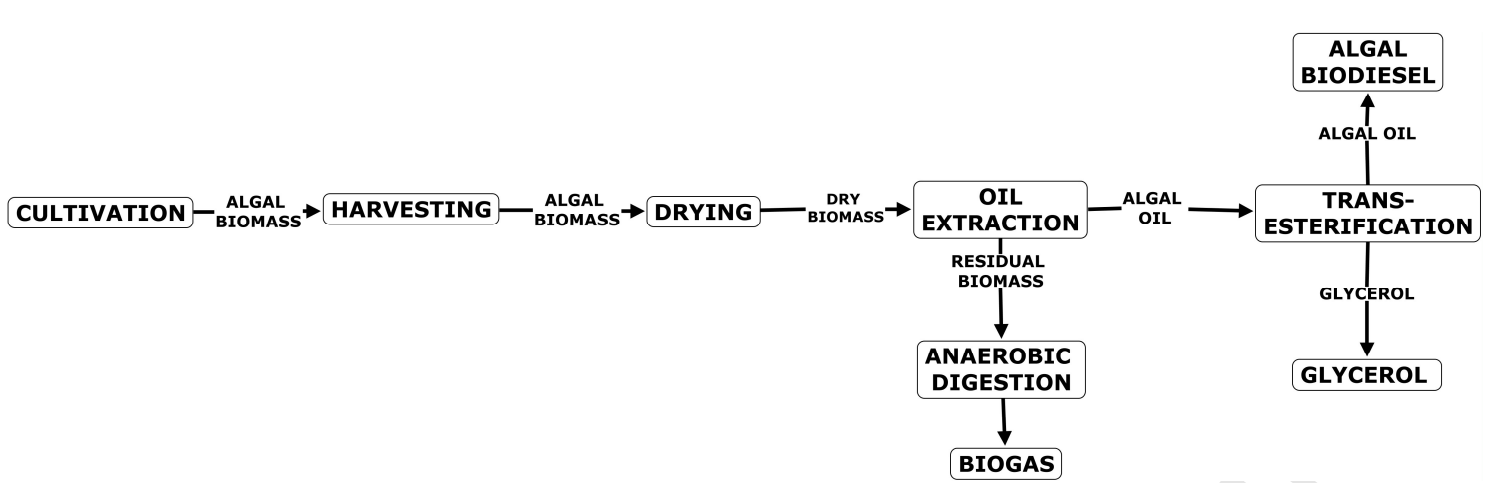

653

Fig. 1

655

655 
656

657

658

659

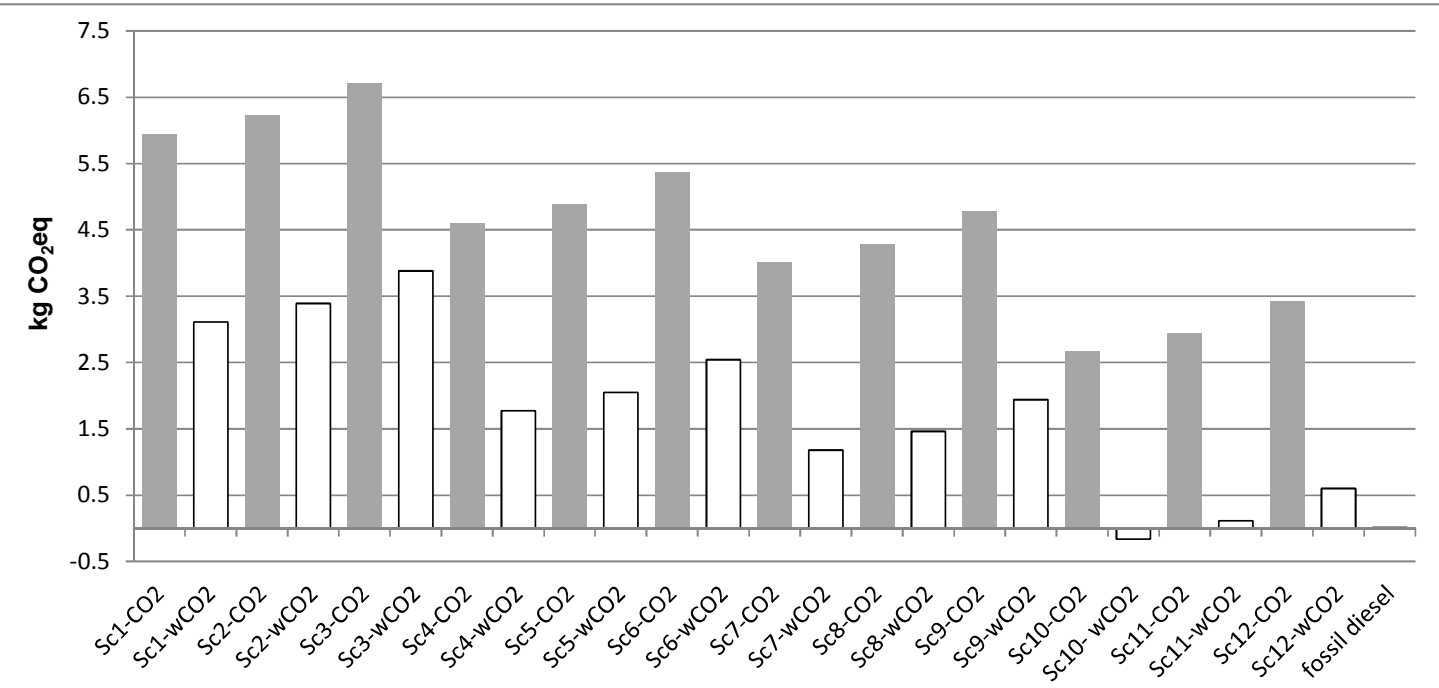

Fig. 2 
660

661

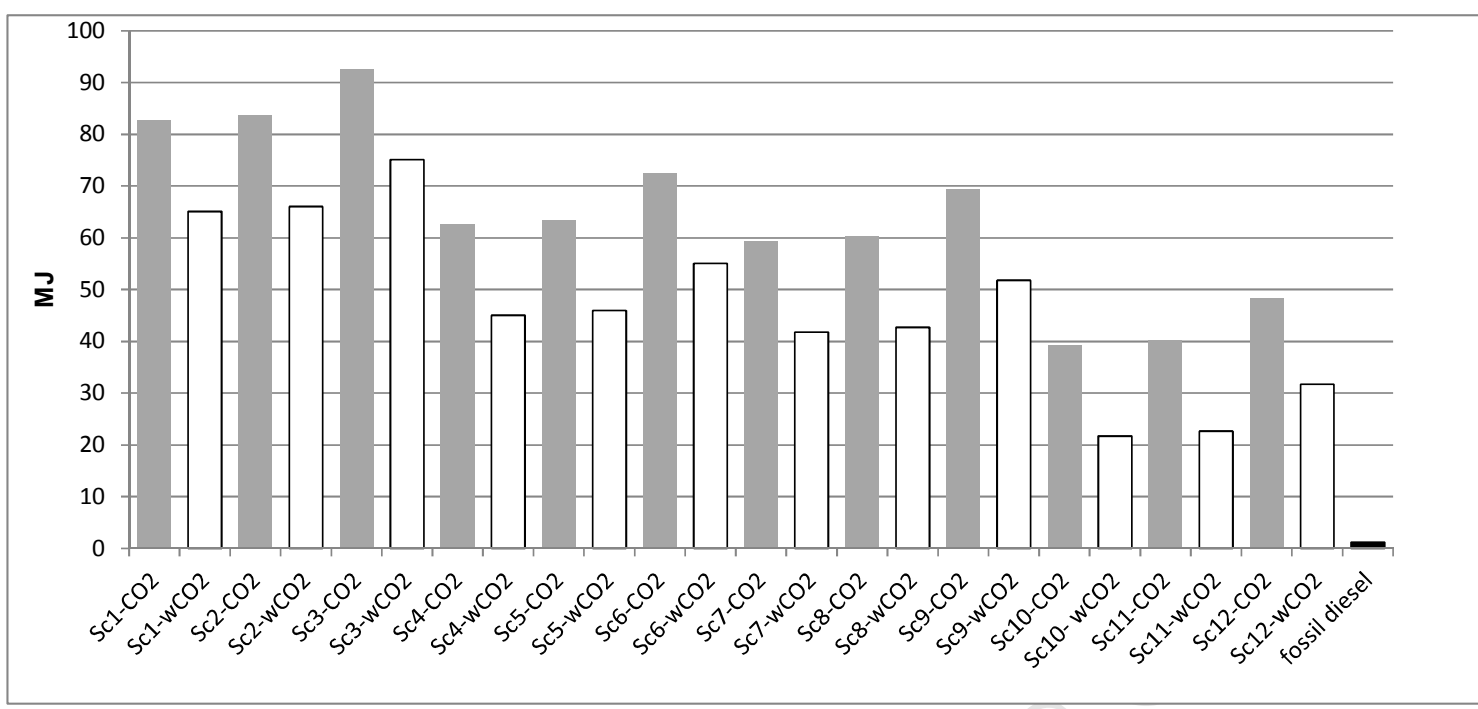

662 Fig. 3

663 


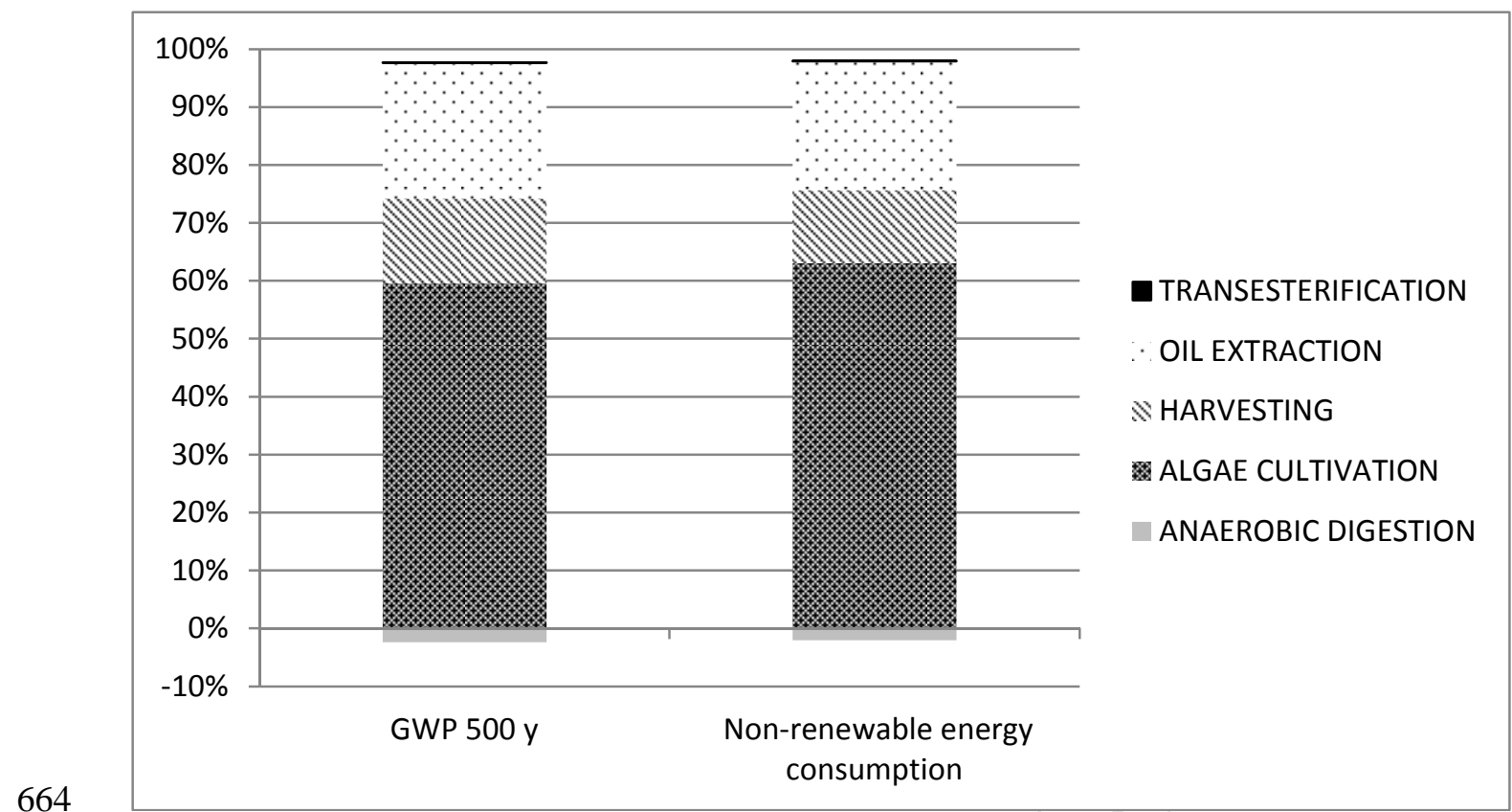

665

Fig. 4

666

667 
668

669

670

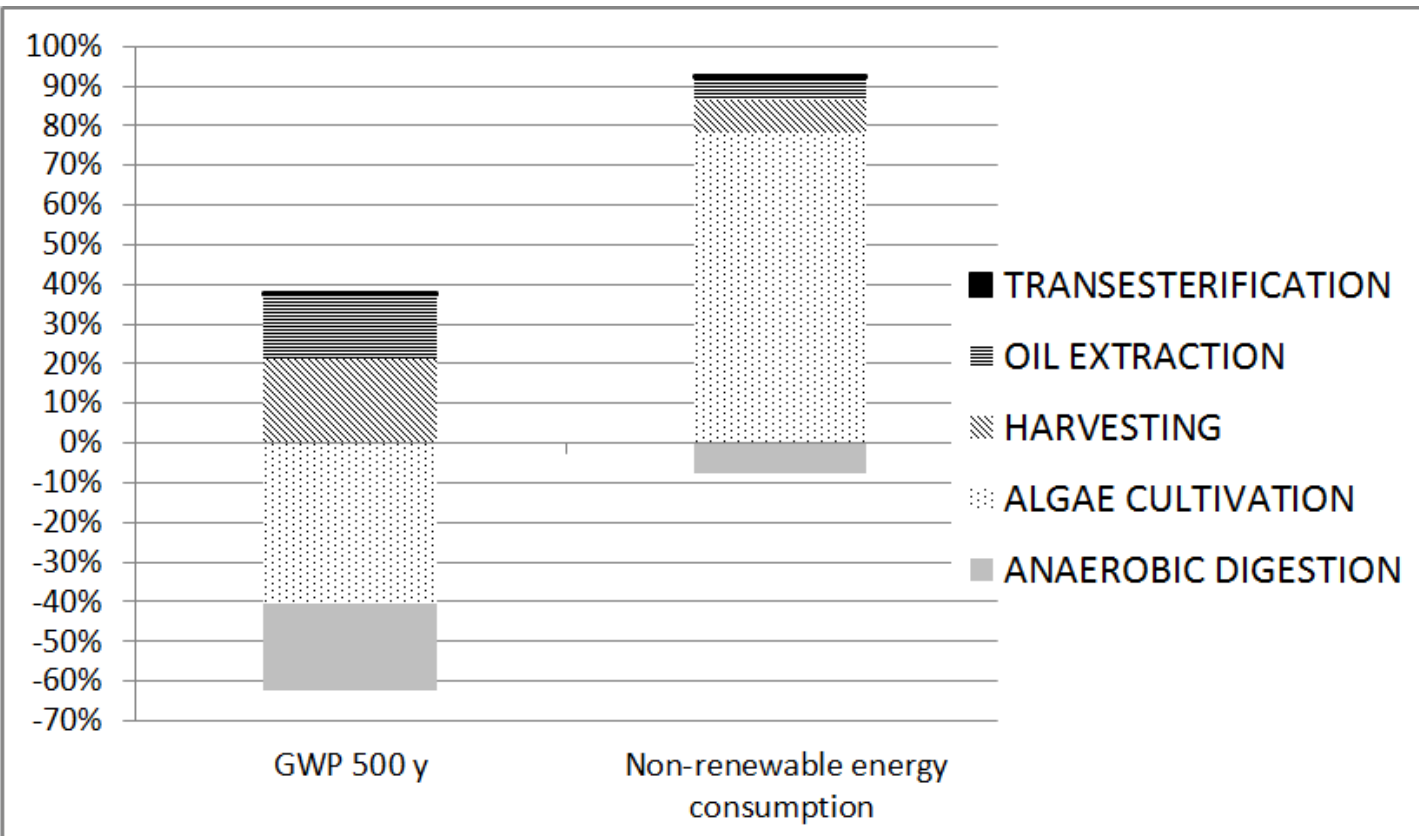

671

Fig. 5 
Supporting information for "Application of LCA approach to Energy and Greenhouse Gas Emission impact of biodiesel production from microalgae cultivated in PBRs: a case study in Denmark" submitted by Monari et al. (2013)

\section{Detailed description of LCI data}

The following detailed tables describe which flows are used and their correspondent processes in Gabi and which database has been used. The processes considered are cultivation (Table 1.1), harvesting and drying (Table 1.2), algal oil extraction (Table 1.3), transesterification (Table 1.4), anaerobic digestion (Table 1.5) and glycerol use (Table 1.6).

\begin{tabular}{|l|l|l|}
\hline FLOWS USED FOR CULTIVATIO & & \\
\hline Flows & Process in Gabi & Database \\
\hline Carbon dioxide $\left(\mathbf{C O}_{2}\right)$ & RER: carbon dioxide liquid at plant & Ecoinvent \\
\hline Water & RER: tap water at user & Ecoinvent \\
\hline Cultivation & DK: electricity production mix & Ecoinvent \\
\hline LDPE sheet & RER: polyethylene LDPE, granulate at plant & Ecoinvent \\
\hline Steel & RER: reinforcing steel at plant & Ecoinvent \\
\hline Ammonium nitrate & $\begin{array}{l}\text { RER: ammonium nitrate, as N, at regional } \\
\text { storehouse }\end{array}$ & Ecoinvent \\
\hline Mono calcium phosphate & $\begin{array}{l}\text { RER: single superphosphate, as } \mathrm{P}_{2} \mathrm{O}_{5}, \text { at } \\
\text { regional storehouse }\end{array}$ & Ecoinvent \\
\hline WASTEWATER CULTIVATION & $\begin{array}{l}\text { Water (wastewater, untreated) [Production } \\
\text { residues in life cycle] }\end{array}$ & Ecoinvent \\
\hline Water & Nitrogen (N-compounds) [Inorganic emissions \\
\hline to air] & Ecoinvent \\
\hline Pitrogen & Phosphorus [Inorganic emissions to air] & Ecoinvent \\
\hline
\end{tabular}

Table 1.1: cultivation phase 


\begin{tabular}{|l|l|l|}
\hline HARVESTING & \multicolumn{2}{|l|}{} \\
\hline Flows used for harvesting & Process in Gabi & Database \\
\hline $\begin{array}{l}\text { Electricity consumption in } \\
\text { flocculation }\end{array}$ & DK: Electricity production mix & Ecoinvent \\
\hline Aluminium sulphate & $\begin{array}{l}\text { RER: aluminium sulphate powder } \\
\text { at plant }\end{array}$ & Ecoinvent \\
\hline Lime CENTRIFUGATION & CH: lime hydrated packed at plant & Ecoinvent \\
\hline $\begin{array}{l}\text { Electricity consumption in } \\
\text { centrifugation }\end{array}$ & DK: Electricity production mix & Ecoinvent \\
\hline \multicolumn{1}{|c|}{ DRYING } & $\begin{array}{l}\text { RER: heat, unspecific at chemical } \\
\text { plant }\end{array}$ & Ecoinvent \\
\hline Heat & & \\
\hline
\end{tabular}

Table 1.2: harvesting and drying phases

\begin{tabular}{|l|l|l|}
\hline EXTRACTION WITH HEXANE & \multicolumn{2}{|l|}{} \\
\hline Flows for algal oil extraction & Process in Gabi & Database \\
\hline $\begin{array}{l}\text { Electricity consumption in hexane } \\
\text { extraction }\end{array}$ & $\begin{array}{l}\text { DK: electricity production } \\
\text { mix }\end{array}$ & Ecoinvent \\
\hline Heat & $\begin{array}{l}\text { RER: heat unspecific at } \\
\text { plant }\end{array}$ & Ecoinvent \\
\hline Hexane & RER: hexane at plant & Ecoinvent \\
\hline $\mathbf{S C O}_{2}$ EXTRACTION & $\begin{array}{l}\text { RER: carbon dioxide liquid } \\
\text { at plant }\end{array}$ & Ecoinvent \\
\hline $\mathrm{CO}_{2}$ liquid & $\begin{array}{l}\text { DK: electricity production } \\
\text { mix }\end{array}$ & Ecoinvent \\
\hline Electricity & & \\
\hline
\end{tabular}

Table 1.3: algal oil extraction phase

\begin{tabular}{|l|l|l|}
\hline \multicolumn{1}{|c|}{ TRANSESTERIFICATION } & \multicolumn{2}{c|}{} \\
\hline Flow & Process in Gabi & Database \\
\hline Electricity consumption & $\begin{array}{l}\text { DK: Electricity production } \\
\text { mix }\end{array}$ & Ecoinvent \\
\hline Heat & $\begin{array}{l}\text { RER: Heat unspecific at } \\
\text { plant }\end{array}$ & Ecoinvent \\
\hline Methanol & GLO: methanol at plant & Ecoinvent \\
\hline
\end{tabular}

Table 1.4: transesterification phase 


\begin{tabular}{|c|c|c|}
\hline \multicolumn{3}{|l|}{ ANAEROBIC DIGESTION } \\
\hline \multicolumn{3}{|l|}{ PRODUCTION OF BIOGAS } \\
\hline Flow & Process in Gabi & Database \\
\hline Electricity & $\begin{array}{l}\mathrm{CH} \text { :electricity, low voltage, } \\
\text { at grid }\end{array}$ & Ecoinvent \\
\hline Plant for Anaerobic digestion & $\begin{array}{l}\mathrm{CH} \text { : anaerobic digestion } \\
\text { plant, biowaste }\end{array}$ & Ecoinvent \\
\hline Transport & $\begin{array}{l}\mathrm{CH} \text { : transport, lorry } 20-28 \mathrm{t} \text {, } \\
\text { fleet average }\end{array}$ & Ecoinvent \\
\hline Transport for municipal waste & $\begin{array}{l}\mathrm{CH} \text { : transport, municipal } \\
\text { waste collection, lorry } 21 \mathrm{t}\end{array}$ & Ecoinvent \\
\hline Heat & $\begin{array}{l}\text { RER: heat, natural gas, at } \\
\text { boiler condensing } \\
\text { modulating }>100 \mathrm{~kW}\end{array}$ & Ecoinvent \\
\hline Municipal solid waste & $\begin{array}{l}\mathrm{CH} \text { : disposal, municipal solid } \\
\text { waste, } 0 \% \text { water, to } \\
\text { municipal incineration } \\
\text { [municipal incineration] }\end{array}$ & Ecoinvent \\
\hline Biogas from biowaste & $\begin{array}{l}\mathrm{CH} \text { : biogas, from biowaste, } \\
\text { at storage [fuels] }\end{array}$ & Ecoinvent \\
\hline \multicolumn{3}{|l|}{ ELECTRICITY FROM BIOGAS } \\
\hline Lubricating oil & RER: lubricating oil, at plant & Ecoinvent \\
\hline Cogen unit for electricity & $\begin{array}{l}\text { RER: cogen unit } 160 \mathrm{kWe} \\
\text { components for electricity } \\
\text { only }\end{array}$ & Ecoinvent \\
\hline Disposal of oil & $\begin{array}{l}\mathrm{CH} \text { : disposal, used mineral } \\
\text { oil, } 10 \% \text { water, to hazardous } \\
\text { waste incineration }\end{array}$ & Ecoinvent \\
\hline Cogen unit for electricity and heat & $\begin{array}{l}\text { RER: cogen unit } 160 \mathrm{kWe} \text {, } \\
\text { common components for } \\
\text { heat+electricity }\end{array}$ & Ecoinvent \\
\hline Biogas & $\begin{array}{l}\text { CH: biogas, production mix, } \\
\text { at storage [fuels] }\end{array}$ & Ecoinvent \\
\hline
\end{tabular}

Table 1.5: anaerobic digestion 


\begin{tabular}{|c|c|c|}
\hline $\begin{array}{c}\text { USE OF GLYCERINE TO } \\
\text { PRODUCE PROPYLENE GLYCOL }\end{array}$ & & \\
\hline Flow & Process in Gabi & Database \\
\hline Electricity use & $\begin{array}{l}\text { UCTE: electricity, medium } \\
\text { voltage, production UCTE, at } \\
\text { grid [production mix] }\end{array}$ & Ecoinvent \\
\hline Heat & $\begin{array}{l}\text { RER: heat, natural gas, at } \\
\text { industrial furnace }>100 \mathrm{~kW}\end{array}$ & Ecoinvent \\
\hline Transport in street & $\begin{array}{l}\text { RER: transport, lorry }>16 t \text {, fleet } \\
\text { average [Street] }\end{array}$ & Ecoinvent \\
\hline Transport in railway & $\begin{array}{l}\text { RER: transport, freight, rail } \\
\text { [Railway] }\end{array}$ & Ecoinvent \\
\hline Chemical plant & RER: chemical plant, organics & Ecoinvent \\
\hline
\end{tabular}

Table 1.6: glycerol use phase 
2. LCIA: the relative contributions of each unit process in cultivation phase In this section, it is possible to observe the different processes used for cultivation and their relative weights to GWP and non renewable energy consumption for each case: freshwater cultivation and "pure $\mathrm{CO}_{2}$ ", wastewater cultivation and "pure $\mathrm{CO}_{2}$ ", freshwater cultivation and waste $\mathrm{CO}_{2}$, wastewater cultivation and waste $\mathrm{CO}_{2}$.

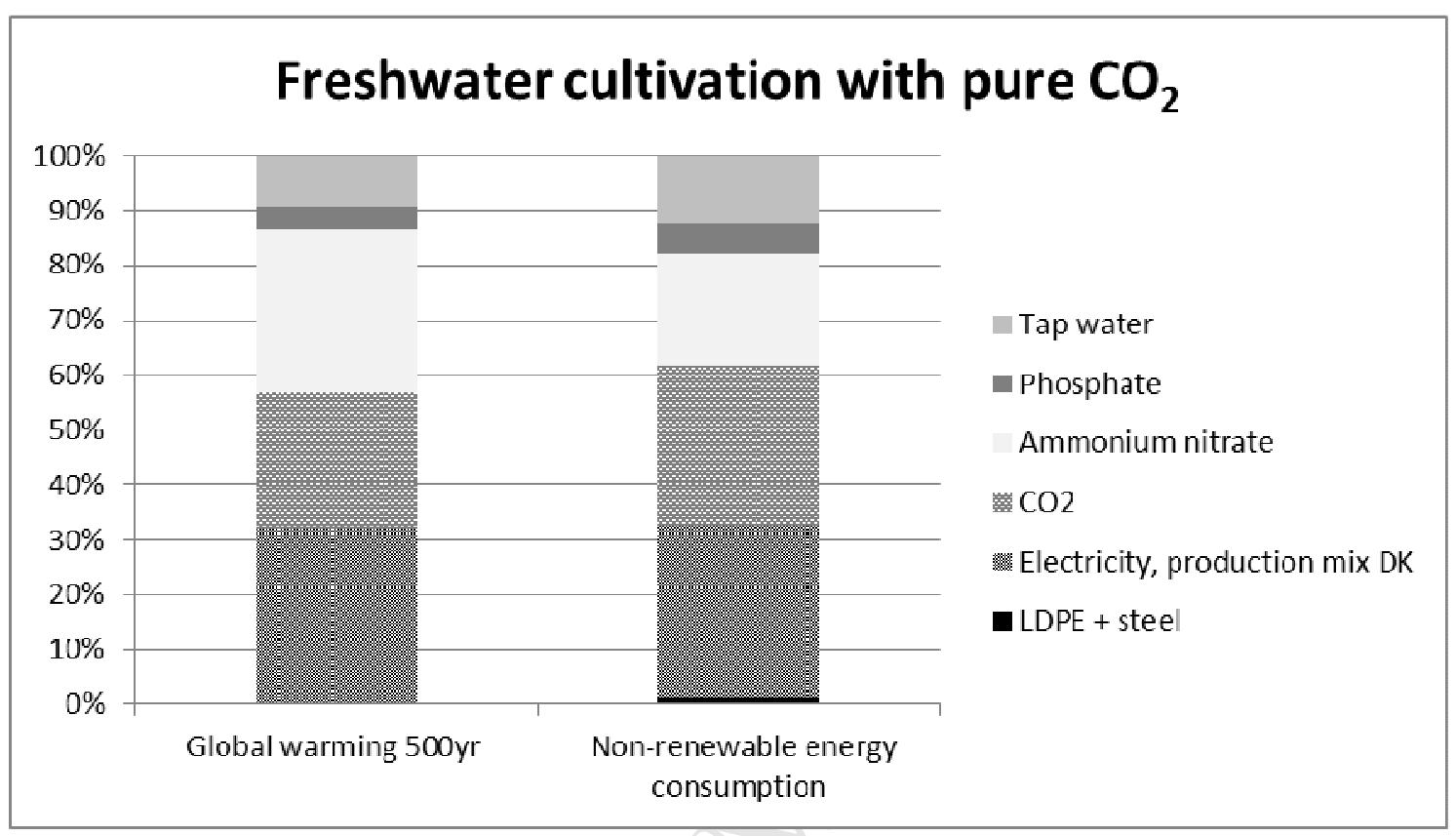

Figure 2.1: contribution of each process unit in freshwater cultivation when "pure" $\mathrm{CO}_{2}$ is used. In this case the unit processes considered are: tap water in which phosphate, ammonium nitrate and $\mathrm{CO}_{2}$ are added, electricity for mixing and pumping $\mathrm{CO}_{2}$ and $\mathrm{LDPE}$ for PBR construction 


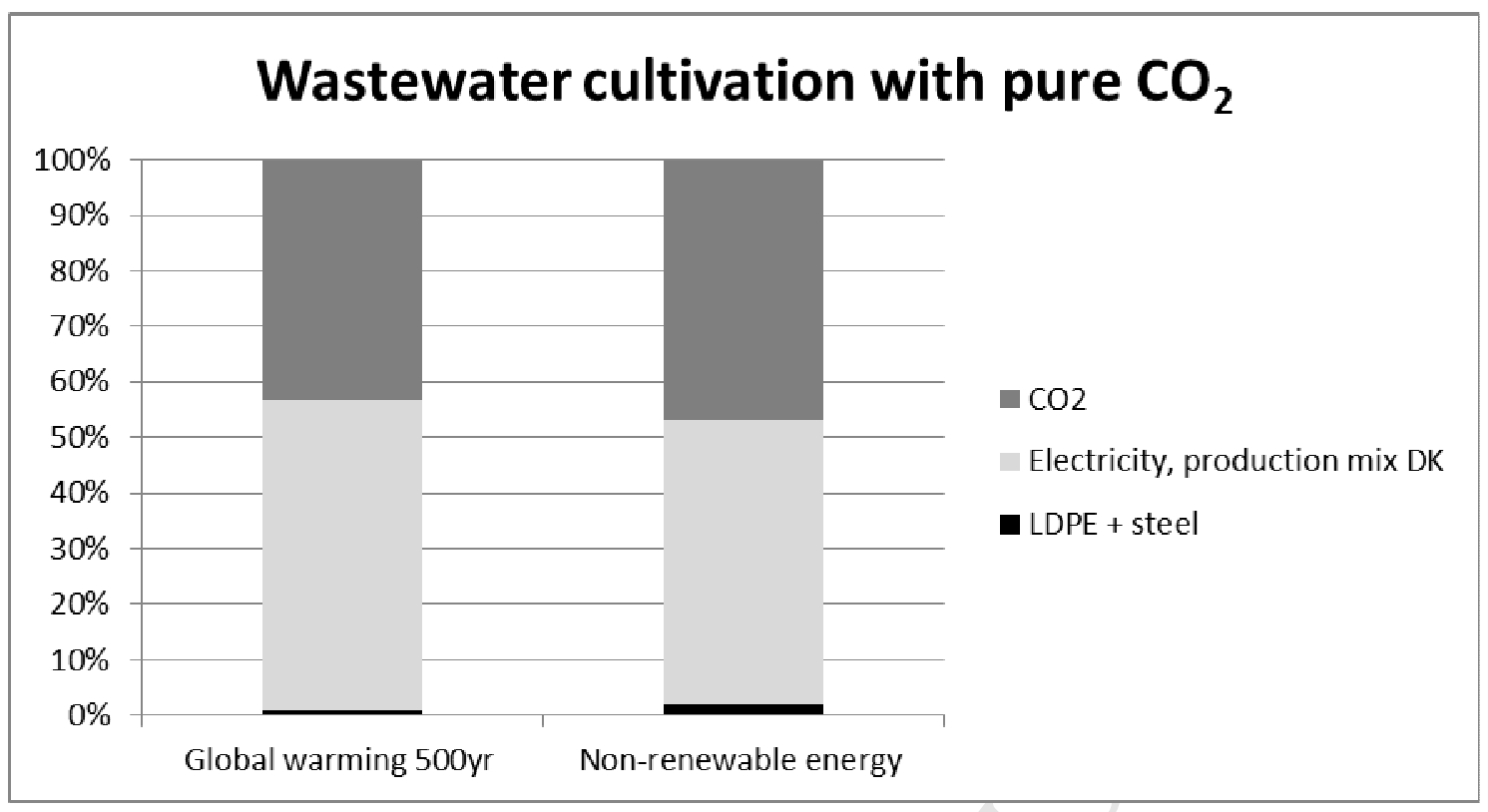

Figure 2.2: contribution of each process unit in wastewater cultivation when "pure" $\mathrm{CO}_{2}$ is used. In this case the unit processes considered are: wastewater (already enriched by phosphorus and nitrogen) in which $\mathrm{CO}_{2}$ is added, electricity for mixing and pumping $\mathrm{CO}_{2}$ and LDPE for PBR construction. In this case, the nutrients are not added to the water

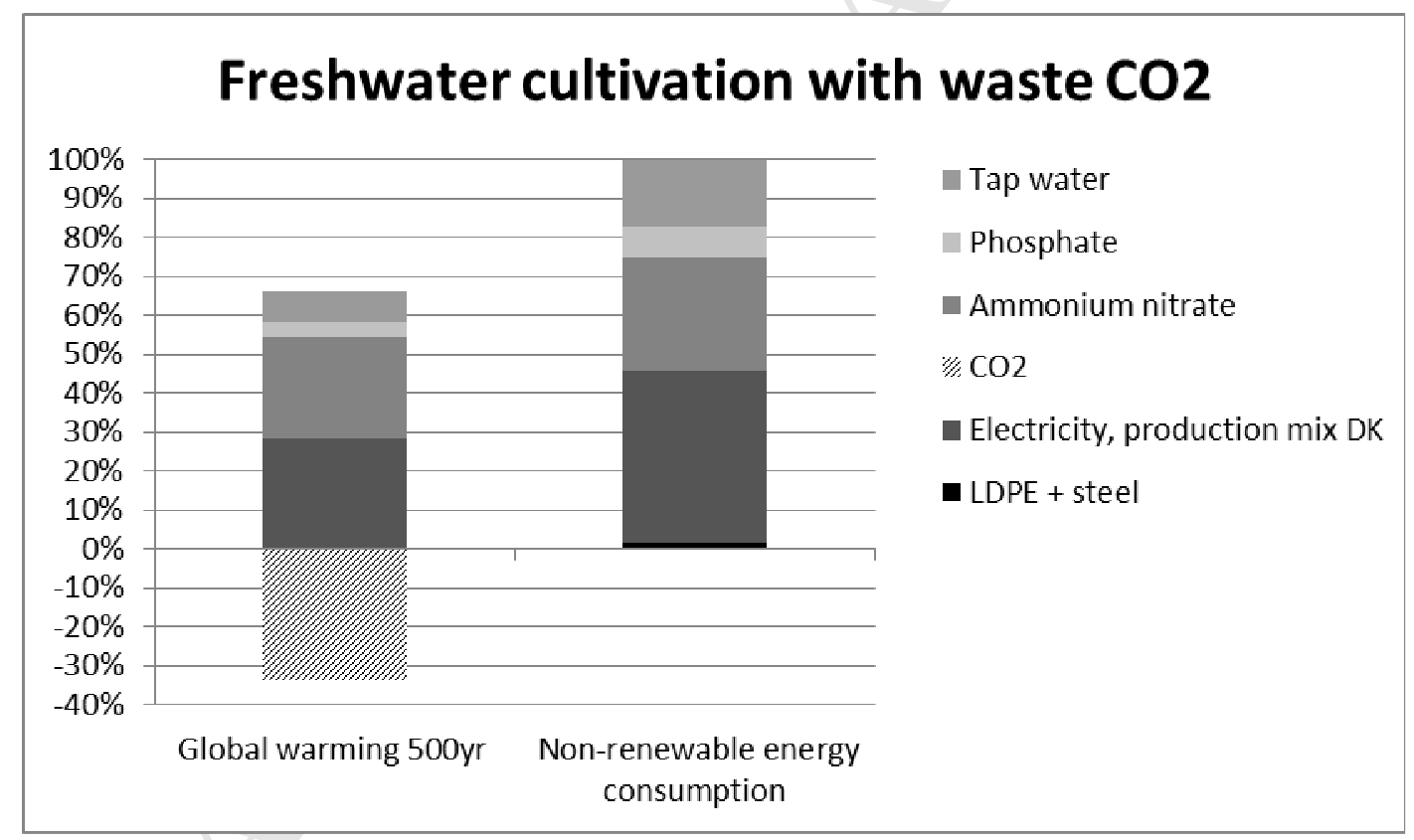

Figure 2.3: contribution of each process unit in freshwater cultivation when waste $\mathrm{CO}_{2}$ from a nearby cement industry is used for algal flow. In this case the unit processes considered are: tap water in which phosphate, ammonium nitrate and $\mathrm{CO}_{2}$ are added, electricity for mixing and pumping $\mathrm{CO}_{2}$ and $\mathrm{LDPE}$ for PBR construction. Since $\mathrm{CO}_{2}$ is a waste flow, the negative contribution of $\mathrm{CO}_{2}$ indicates that the flow does not take into account its production process 


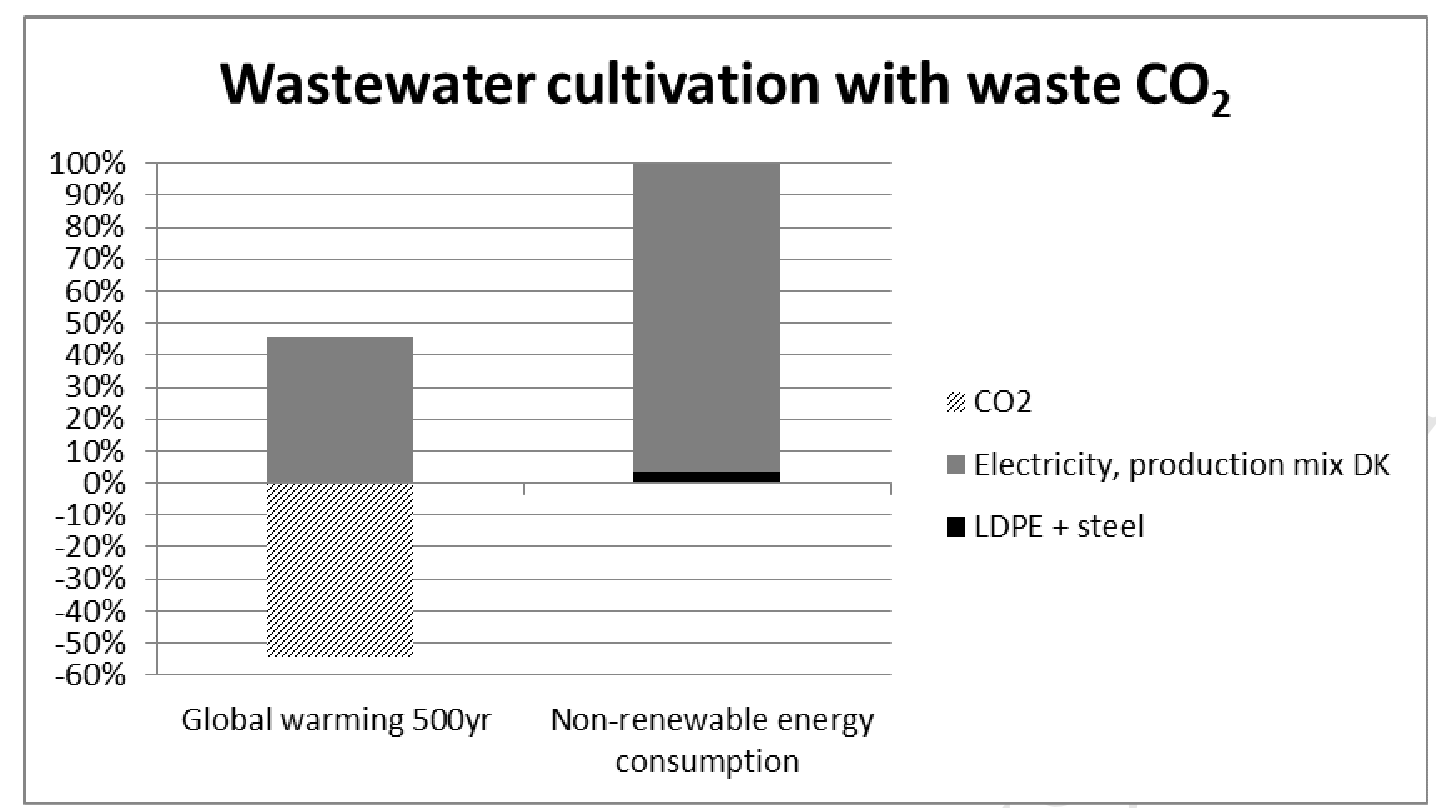

Figure 2.4: contribution of each process unit in wastewater cultivation when waste $\mathrm{CO}_{2}$ from a nearby cement industry is considered. In this case the unit processes considered are: wastewater (already enriched by phosphorus and nitrogen) in which $\mathrm{CO}_{2}$ is added, electricity for mixing and pumping $\mathrm{CO}_{2}$ and $\mathrm{LDPE}$ for PBR construction. In this case, the nutrients are not added to the water and since $\mathrm{CO}_{2}$ is a waste flow, the negative contribution of $\mathrm{CO}_{2}$ indicates that the flow does not take into account its production process 